\title{
PROSES PENDEMOKRASIAN DI TURKI: ANALISIS TERHADAP PINDAAN PERLEMBAGAAN TAHUN 2010 \\ (Democratization in Turkey: An Analysis on the 2010 Constitutional Amendment)
}

\author{
Muhammad Khalis Ibrahim* \& Asyiqin Ab Halim**
}

\begin{abstract}
Abstrak
Proses sekularisasi yang dilaksanakan di Turki turut memberi kesan kepada perlembagaan negara tersebut. Perlembagaan Turki yang beridentiti sekular menjadikannya sebagai sebuah kontrak sosial yang bersifat mencengkam dan mengekang kebebasan individu, termasuklah untuk mengamalkan agama secara bebas. Kemunculan Parti Keadilan dan Pembangunan (Adalet ve Kalkınma Partisi, AKP) dengan wacana demokrasi konservatif cenderung untuk membuka ruang kebebasan yang lebih luas, termasuklah untuk membolehkan pengamalan agama dilakukan secara bebas. Justeru, artikel ini bertujuan untuk menganalisis proses pendemokrasian di Turki yang dilakukan oleh AKP menerusi pindaan perlembagaan pada tahun 2010. Artikel ini menganalisis secara langsung Perlembagaan Turki sebagai sumber primer kajian dengan meneliti perbezaan sebelum dan selepas pindaan pada tahun tersebut. Selain itu, senario sepanjang proses pindaan perlembagaan dilakukan turut dianalisis secara mendalam. Secara keseluruhan, pindaan perlembagaan tahun 2010 sememangnya menyumbang kepada proses pendemokrasian di Turki. Pindaan tersebut memberi kesan kepada kedudukan hak asasi rakyat, di samping tentera dan badan kehakiman yang selama ini diperuntukkan dengan bidang kuasa yang luas. Sebagai sebuah negara sekular, proses pendemokrasian merupakan langkah yang berkesan di Turki untuk membuka ruang kepada kebebasan pengamalan agama masyarakat.
\end{abstract}

Kata kunci: Pendemokrasian, demokrasi, Perlembagaan Turki, pindaan perlembagaan tahun 2010, AKP

\begin{abstract}
The process of secularization implemented in Turkey has affected the constitution of the country. Turkey's secular constitution acts as a social contract that restricted the freedom of an individual, including to practice religion. The emergence of the Justice and Development Party (Adalet ve Kalkınma Partisi, AKP) with conservative democracy discourse tends to create a wider space of liberty, including religious freedom. Thus, this article aims to analyze the democratization process in Turkey practiced by the AKP through the amendment of the constitution in 2010. Furthermore, it analyzed the Constitution of Turkey as the primary source of this study by examining the differences pre and post of its amendment in 2010. Besides, the process of the constitutional amendment is also analyzed thoroughly. Overall, the 2010 constitutional amendment contributed to the process of democratization in Turkey, where it has affected the rights of the people, the military, and judiciary which have been given extensive jurisdiction. As a secular country, the process of democratization in Turkey was an effective step for freedom of religious practice.
\end{abstract}

Keywords: Democratization, democracy, Constitution of Turkey, 2010 constitutional amendment, AKP

\section{Pengenalan}

Proses sekularisasi yang dilaksanakan semasa pembentukan Republik Turki moden telah mencetuskan polemik yang hangat di negara tersebut. Keberadaan Islam sebagai asas identiti masyarakat Turki sejak sekian lama telah cuba dinafikan oleh Mustafa Kemal Atatürk, iaitu pengasas negara Turki moden. Proses sekularisasi secara radikal telah dilaksanakan dengan harapan supaya masyarakat Turki meninggalkan warisan dan tradisi Islam di atas alasan menjadikan masyarakat Turki lebih maju dan setanding dengan negara-negara Barat. Walaupun selepas ketiadaan Atatürk, gagasan tersebut terus

\footnotetext{
${ }^{*}$ Muhammad Khalis Ibrahim, Research Assistant, Department of Islamic History and Civilization, Academy of Islamic Studies, University of Malaya, Kuala Lumpur, Malaysia. E-mail: khalismuhammad92@yahoo.com.

${ }_{* *}$ Asyiqin Ab Halim (Corresponding Author), Senior Lecturer, Department of Islamic History and Civilization, Academy of Islamic Studies, University of Malaya, Kuala Lumpur, Malaysia. E-mail: aasyiq5@um.edu.my.
} 
diperjuangkan oleh pendukung Kemalis ${ }^{1}$ sehinggakan pada fasa ini, prinsip sekularisme semakin diperketatkan pengamalannya dalam segenap aspek.

Proses sekularisasi yang dilaksanakan di Turki turut memberi kesan kepada perlembagaan negara tersebut. Lantaran sifatnya yang sekular, Perlembagaan Turki tidak memberi ruang kepada pengamalan agama untuk dilaksanakan secara bebas sama ada di peringkat negara mahupun dalam keadaan tertentu, di peringkat individu. Malah, tentera diberikan kuasa yang luas di dalam Perlembagaan Turki yang memberikan ia sumber legitimasi bagi melakukan sebarang tindakan yang difikirkan perlu berdasarkan alasan "memelihara keselamatan negara," meskipun tindakannya ada yang bercanggah dengan prinsip demokrasi. Hal ini menjadikan Perlembagaan Turki sebagai sebuah kontrak sosial yang bersifat mencengkam dan mengekang kebebasan individu, termasuklah untuk mengamalkan agama secara bebas.

Kemunculan Parti Keadilan dan Pembangunan (Adalet ve Kalkınma Partisi, AKP) dengan wacana demokrasi konservatif dilihat cuba mengharmonikan antara elemen-elemen tradisi menerusi kerangka konservatisme dan elemen-elemen demokrasi bagi membuka ruang kepada kebebasan yang lebih luas, merangkumi usaha-usaha untuk membolehkan pengamalan agama dilakukan secara bebas. Bagi AKP, proses pendemokrasian merupakan langkah penting untuk membolehkan Turki menjadi sebuah negara yang demokratik, sekaligus bertindak sebagai penampan kepada keluasan kuasa tentera dan badan kehakiman yang selama ini mengambil kesempatan di sebalik alasan "memelihara prinsip sekularisme." Antara usaha yang dilakukan di bawah proses pendemokrasian ialah dengan mereformasi Perlembagaan Turki yang selama ini banyak mencetuskan polemik antara negara dan rakyat serta elit sekular dan masyarakat terbanyak.

Artikel ini bertujuan untuk menganalisis proses pendemokrasian di Turki yang dilakukan oleh AKP menerusi pindaan perlembagaan pada tahun 2010. Artikel ini menganalisis secara langsung Perlembagaan Turki sebagai sumber primer kajian dengan meneliti perbezaan sebelum dan selepas pindaan pada tahun tersebut. Selain itu, senario sepanjang proses pindaan perlembagaan dilakukan turut dianalisis secara mendalam. Secara strukturnya, artikel ini dimulakan dengan sorotan latar belakang pembentukan Perlembagaan Turki dan polemik yang tercetus di sebalik Perlembagaan Turki. Seterusnya ia membincangkan proses pindaan perlembagaan yang dilakukan pada tahun 2010, diikuti dengan analisis terhadap intipati pindaan.

\section{Latar Belakang Pembentukan Perlembagaan Negara Turki Moden}

Jika dilihat sejarah penggubalan Perlembagaan Turki, Perlembagaan Turki yang terkini tidak muncul secara sendiri. Sebaliknya, ia merupakan rentetan daripada beberapa perlembagaan yang telah wujud sebelumnya. Perlembagaan Turki pada dasarnya berakar umbi daripada Perlembagaan Uthmaniyyah 1876 yang digubal semasa kepimpinan Sultan Abd al-Hamid II (1876-1908). ${ }^{2}$ Penggubalan perlembagaan tersebut dicetuskan oleh kumpulan Uthmani Muda sebagai sebahagian daripada usaha pemodenan dan pembaratan di bawah program Tanzimat. ${ }^{3}$ Tanzimat ialah program penyusunan dan penstrukturan semula dasar dan undang-undang Khilafah Uthmaniyyah dengan bermatlamat mewujudkan sistem perundangan yang menjamin hak rakyatnya tanpa mengira agama dan kaum. Dari sudut idea, Tanzimat menerima inspirasi daripada tamadun Barat yang pada ketika itu sedang menyaksikan kemajuan baik dari sudut ketenteraan, ekonomi, politik, perundangan mahupun sains dan teknologi. Disebabkan hal ini, perlembagaan yang digubal menerima pengaruh yang kuat daripada perundangan Barat khususnya perlembagaan Belgium dan Prussia walaupun pada masa yang sama, kedudukan Islam sebagai agama rasmi negara terus dikekalkan. ${ }^{4}$ Namun, perlembagaan yang digunakan beserta parlimen Uthmaniyyah telah digantung oleh Sultan Abd al-Hamid pada 14 Februari 1878 setelah mendapati parlimen menjadi medan untuk mengkritik dasar-dasar yang dilaksanakan oleh beliau. Perlembagaan tersebut hanya dilaksanakan semula pada tahun 1908 selepas Sultan Abd alHamid menerima desakan daripada kumpulan Turki Muda. Perlembagaan Uthmaniyyah 1876 yang

\footnotetext{
${ }^{1}$ Kemalis merujuk kepada mereka yang mendukung idea sekularisme yang dibawa oleh Mustafa Kemal Atatürk.

2 Asl1 Topukcu (2014), "The Processes and the Principles of Constitutional Design in Turkey: Historical and Legal Perspective," Makalah, World Congress of Constitutional Law 2014, Oslo, Norway, 16-20 Jun, h. 3.

${ }^{3}$ Mehmet Maksudoğlu (1999), Osmanlı History 1289-1922: Based on Osmanlı Sources, Gombak: Research Centre, International Islamic University Malaysia, h. 212.

${ }^{4}$ Mohamad Shaukhi Mohd Radzi (2016), Proses Pembaratan dalam Daulah Uthmaniyyah 1789-1876, Sabah: Penerbit Universiti Malaysia Sabah, h. 130 .
} 
dilaksanakan semula beserta pindaan secara tersiratnya bertujuan memberikan kuasa yang lebih luas kepada cabang legislatif dan mengurangkan bidang kuasa sultan. Namun begitu, perlembagaan tersebut kemudiannya terpaksa dimansuhkan berikutan keterlibatan kerajaan Uthmaniyyah di dalam Perang Dunia Pertama.

Berikutan kekalahan Uthmaniyyah dalam Perang Dunia Pertama, Kuasa Berikat telah memasuki wilayah Anatolia dan mengepung Istanbul yang merupakan pusat pentadbiran Uthmaniyyah pada ketika itu. Kemasukan Kuasa Berikat ke wilayah Anatolia telah mendesak kepada penubuhan kerajaan baharu yang berpusat di Ankara. Perhimpunan Agung Kebangsaan Turki atau parlimen Turki pimpinan Mustafa Kemal telah meluluskan penggubalan Perlembagaan Turki 1921 (selepas ini dirujuk sebagai "Perlembagaan 1921") dengan mengambil contoh daripada Perlembagaan Uthmaniyyah 1876. Namun, perlembagaan kali ini mempunyai kelainannya yang tersendiri. Perlembagaan 1921 mengandungi 23 artikel yang banyak memfokuskan kepada bidang kuasa parlimen di samping turut memuatkan peruntukan mengenai hal ehwal perbandaran dan pentadbiran. ${ }^{5}$ Secara umumnya, Perlembagaan 1921 boleh dikatakan sebagai kontrak sosial yang dirangka bagi persediaan penubuhan negara Turki moden. Ia memuatkan beberapa peruntukan yang menjelaskan asas-asas bagi penubuhan sebuah negara bangsa moden. Misalnya, pada Artikel 1 menjelaskan perihal kedaulatan negara bangsa yang menjadi asas kepada penubuhan negara Turki moden. Di samping itu, Artikel 2 dan 3 menyebut bahawa kuasa eksekutif dan legislatif terletak sepenuhnya di bawah bidang kuasa parlimen. Penekanan Perlembagaan 1921 kepada bidang kuasa parlimen boleh dilihat berdasarkan dua sudut. Pertama, ia membayangkan kecenderungan Mustafa Kemal yang berusaha untuk meminggirkan kuasa dan peranan sultan. Hal ini terbukti di mana pada tahun berikutnya, kesultanan Uthmaniyyah telah dimansuhkan oleh kabinet parlimen di bawah kepimpinan beliau. Kedua, ia merupakan reaksi daripada perkembangan pasca Perang Dunia Pertama. Selepas tamatnya Perang Dunia Pertama, institusi kesultanan Uthmaniyyah masih wujud secara zahirnya. Namun, ia tidak lagi mempunyai kuasa dan kedaulatan seperti sebelumnya.

Penubuhan negara Republik Turki secara rasmi pada 29 Oktober 1923 telah mendesak penggubalan perlembagaan baharu yang lebih komprehensif. Secara asasnya, penggubalan perlembagaan baharu bertujuan menggantikan sistem dwi-perundangan, di mana satu daripadanya berasaskan perundangan sivil, manakala satu lagi berasaskan syariat. ${ }^{6}$ Selain itu, perlembagaan baharu yang digubal turut berperanan sebagai kerangka asas bagi penubuhan negara Turki moden. Akhirnya pada 23 April 1924, Perlembagaan Turki 1924 (selepas ini dirujuk sebagai "Perlembagaan 1924") yang merupakan perlembagaan pertama selepas penubuhan negara Republik Turki telah digubal dan dilaksanakan secara rasmi. Di dalam perlembagaan tersebut, perkara-perkara yang menjadi aspek penting bagi pembentukan identiti negara Turki moden telah dijelaskan. Antaranya, Artikel 1 menyebutkan negara Turki yang dibentuk merupakan sebuah republik, di mana perkara ini tidak boleh dipinda melalui sebarang pindaan (Artikel 102). Dalam Artikel 2 pula telah diperuntukkan Islam sebagai agama rasmi negara, Bahasa Turki sebagai bahasa rasmi kebangsaan serta Ankara sebagai ibu negara Republik Turki. Status kerakyatan turut dinyatakan di dalam Artikel 88 yang menjelaskan bahawa kerakyatan Turki adalah berdasarkan sempadan geografi dan politik sebagai identiti kerakyatan tanpa mengambil kira aspek agama dan etnik. Selain itu, struktur kerajaan Republik Turki yang berasaskan perwakilan turut diperkasakan melalui beberapa artikel di samping peruntukan-peruntukan mengenai kuasa Presiden, badan eksekutif, kehakiman dan undang-undang awam. ${ }^{7}$ Perlembagaan tersebut berkuat kuasa selama 36 tahun sebelum diganti dengan perlembagaan baharu pada tahun 1961. Sepanjang tempoh tersebut, tujuh kali pindaan telah dilakukan termasuklah pindaan terhadap status Islam sebagai agama rasmi negara (1928), pemberian hak kepada kaum wanita untuk mengundi dan dipilih sebagai ahli parlimen (1934) serta pengadaptasian prinsip sekularisme (1937). ${ }^{8}$

Reformasi politik pada era İsmet İnönü (1938-1950), terutamanya berhubung sistem pelbagai parti sejak tahun 1946; telah mencetuskan perbincangan mengenai keperluan kepada perlembagaan baharu yang lebih demokratik. Di sudut yang lain pula, perkembangan politik Turki pada era 1950-an telah

\footnotetext{
${ }^{5}$ Untuk terjemahan Bahasa Inggeris bagi Perlembagaan 1921, lihat Ö. F. Gençkaya (t.t.), "The 1921 Constitution (Selections)," Anayasa, dicapai 17 September 2017, http://genckaya.bilkent.edu.tr/1921C.html.

${ }^{6}$ Topukcu (2014), “The Processes and the Principles of Constitutional Design in Turkey,” h. 4.

${ }^{7}$ Untuk terjemahan Bahasa Inggeris bagi Perlembagaan 1924, lihat Edward Mead Earle (1925), "The New Constitution of Turkey," Political Science Quarterly, Jil. 40, Bil. 1, h. 89-100.

${ }^{8}$ Friedrich Ebert Stiftung (2011), "On the Way to a New Constitution in Turkey: Consitutional History, Political Parties and Civil Platform," dicapai 3 November 2017, http://library.fes.de/pdf-files/bueros/tuerkei/12220.pdf.
} 
memperlihatkan suasana tegang antara pendukung Parti Republikan Rakyat (Cumhuriyet Halk Partisi, CHP) dan pendukung Parti Demokrat (Demokrat Partisi, DP). ${ }^{9}$ Perkembangan ini mendesak angkatan tentera Turki untuk melakukan rampasan kuasa pada 27 Mei 1960 yang sekaligus turut bertindak menggantung perlembagaan sedia ada. Pada tahun berikutnya, Perlembagaan Turki yang baharu, atau Perlembagaan Turki 1961 (selepas ini dirujuk sebagai "Perlembagaan 1961") telah digubal dan dikuat kuasakan bagi menggantikan Perlembagaan 1924. Perlembagaan 1961 merupakan Perlembagaan Turki pertama yang melibatkan Lembaga Perundangan yang dibentuk khas di samping melibatkan referendum rakyat. Perlembagaan 1961 dilihat kontroversial sama ada dari sudut pihak yang terlibat menggubalnya mahupun intipati perlembagaan itu sendiri. Lembaga Perundangan selaku badan yang bertanggungjawab menggubal Perlembagaan 1961 dibahagikan kepada dua bahagian. Bahagian yang pertama dianggotai oleh pegawai-pegawai tentera yang menganggotai Jawatankuasa Perpaduan Negara, iaitu entiti utama yang terlibat di dalam rampasan kuasa tahun 1960. Bahagian kedua pula dipilih oleh ahli Lembaga Perundangan. ${ }^{10}$ Ini bermaksud, Perlembagaan 1961 digubal secara langsung oleh tentera yang sememangnya dikenali sebagai pemelihara tegar prinsip sekularisme.

Secara umumnya, falsafah Perlembagaan $1961^{11}$ adalah berpaksikan kepada hak asasi sepertimana yang dinyatakan di dalam pendahuluan dan Artikel 2 perlembagaan tersebut. Elemen hak asasi yang ditekankan di dalam Perlembagaan 1961 merupakan reaksi terhadap corak kempimpinan Adnan Menderes yang dikatakan kurang memberi tempat terhadap elemen tersebut. ${ }^{12}$ Namun, tumpuan Perlembagaan 1961 yang lebih berfokus kepada aspek hak asasi telah menerima kritikan ramai pihak kerana kurang memberi penekanan terhadap elemen solidariti dan kenegaraan. ${ }^{13}$ Berbeza dengan Perlembagaan 1924, Perlembagaan 1961 ditambah baik dengan memperincikan pengasingan kuasa legislatif, eksekutif dan kehakiman, di mana hal ini kurang ditekankan di dalam perlembagaan sebelumnya dan menyebabkan cabang legislatif sangat berkuasa sehingga mempengaruhi bidang kuasa eksekutif. ${ }^{14}$ Bagi memastikan konsep kedaulatan undang-undang diperkasakan, aspek kehakiman telah diperkukuhkan peranannya melalui penubuhan Mahkamah Perlembagaan berdasarkan peruntukan di dalam Artikel 145 sehingga Artikel 152. Sebarang enakmen yang diputuskan di peringkat legislatif atau parlimen perlulah melalui semakan Mahkamah Perlembagaan terlebih dahulu. ${ }^{15}$ Perlembagaan 1961 telah mengalami enam kali pindaan sepanjang tempoh 19 tahun pengadaptasiannya, di mana pindaan tahun 1971 dan 1973 adalah pindaan paling signifikan bagi mengawal krisis politik yang melanda Turki ketika itu. ${ }^{16}$

Walau bagaimanapun, Perlembagaan 1961 tetap tidak mampu untuk mengawal ketidak stabilan yang melanda. Seiring dengan fasa kemuncak Perang Dingin, tahun 1970-an menyaksikan wujudnya polarisasi politik yang melampau, khususnya dengan kewujudan kelompok kiri-sosialis. Hal ini telah mencetuskan ketidak stabilan politik yang akhirnya mendesak pihak tentera untuk sekali lagi melakukan campur tangan politik. Rampasan kuasa pada 12 September 1980 menyebabkan tentera bertindak menggantung perlembagaan sedia ada. Rampasan kuasa pada tahun tersebut dilaksanakan berdasarkan doktrin "memelihara keselamatan negara" yang berbeza konteksnya dengan rampasan kuasa pada tahun 1960 yang berasaskan doktrin "menangani autoritarianisme," iaitu merujuk kepada pemerintahan era DP yang kurang mementingkan nilai hak asasi. Senario tersebut mendesak kepada keperluan penggubalan perlembagaan baharu bagi mewujudkan keamanan dan keharmonian. ${ }^{17}$ Proses merangka perlembagaan baharu melibatkan Majlis Keselamatan Negara (Milli Güvenlik Kurulu, MGK) ${ }^{18}$ selaku

\footnotetext{
${ }^{9} \mathrm{CHP}$ merupakan parti politik pertama yang diwujudkan sejak penubuhan negara Turki moden. Ia diasaskan sendiri oleh Atatürk, sekaligus merupakan parti yang mendukung idea Kemalisme. CHP menjadi parti yang memerintah Turki secara sendirian berikutan pelaksanaan sistem parti tunggal sejak tahun 1923. Manakala DP pula merupakan parti yang ditubuhkan oleh beberapa bekas pemimpin CHP serta ahli politik liberal di bawah pimpinan Celal Bayar dan Adnan Menderes. DP menjadi parti pertama yang berjaya menewaskan CHP selepas Turki melaksanakan sistem pelbagai parti pada tahun 1946.

${ }^{10}$ Ergun Özbudun (2012), “Turkey's Search for a New Constitution,” Insight Turkey, Jil. 14, Bil. 1, h. 40.

${ }^{11}$ Untuk terjemahan Bahasa Inggeris bagi Perlembagaan 1961, lihat Sadık Balkan, Ahmet E. Uysal dan Kemal H. Karpat (1961), Constitution of the Turkish Republic, Ankara.

${ }^{12}$ Ozan O. Varol (2013), "The Turkish “Model” of Civil-Military Relations," International Journal of Constitutional Law, Jil. 11, Bil. 3, h. 736-739.

${ }^{13}$ Topukcu (2014), “The Processes and the Principles of Constitutional Design in Turkey,” h. 7.

${ }^{14}$ Ismet Giritli (1962), "Some aspects of the new Turkish Constitution," The Middle East Journal, Jil. 16, Bil. 1, h. 9-10.

${ }^{15}$ Giritli (1962), "Some aspects of the new Turkish Constitution," h. 10.

${ }^{16}$ Muzaffer Sencer (t.t.), "From the Constitution 1961 to the Constitution 1982," Turkish Yearbook of Human Rights, h. 16

${ }^{17}$ Topukcu (2014), “The Processes and the Principles of Constitutional Design in Turkey," h. 7.

${ }^{18}$ MGK ditubuhkan rentetan daripada rampasan kuasa kali pertama d Turki pada tahun 1960 dan kewujudannya diperuntukkan di dalam Perlembagaan 1961. MGK merupakan badan tertinggi yang bertanggungjawab dalam menentukan urusan hal ehwal keselamatan negara Turki. Pada asalnya, MGK dianggotai oleh Presiden, Perdana Menteri, Menteri Luar, Menteri Pertahanan, Menteri Dalam Negeri dan lima orang pegawai tertinggi dalam TSK. Kini, ia dianggotai oleh Presiden, Timbalan Presiden, Menteri Keadilan, Menteri Luar, Menteri Pertahanan,
} 
penggerak utama rampasan kuasa 1980 secara langsung serta Himpunan Perundingan yang ahlinya dipilih sendiri oleh MGK. Perlembagaan baharu yang digubal, atau Perlembagaan Turki 1982 (selepas ini dirujuk sebagai "Perlembagaan Turki") turut melibatkan referendum nasional. Tekanan politik ketika itu menyebabkan draf perlembagaan tersebut disokong secara majoriti oleh 91 peratus rakyat Turki dan dikuat kuasakan bermula 7 November 1982, menjadi perlembagaan negara yang paling lama bertahan dan masih digunakan sebagai sumber perundangan tertinggi Turki sehingga kini.

\section{Polemik di Sebalik Perlembagaan Turki}

Memandangkan Perlembagaan Turki yang digubal pada tahun 1982 merupakan produk pasca rampasan kuasa tentera, ia memperlihatkan ciri-ciri autoritarian pihak tentera selaku perangka utamanya. ${ }^{19}$ Malah, semasa fasa pembentukannya, keterlibatan wakil dari parti-parti politik telah dinafikan memandangkan parti-parti politik telah diharamkan atau dibekukan aktivitinya pada fasa tersebut. Hal ini menyebabkan Perlembagaan Turki menjadi penyumbang kepada beberapa polemik, khususnya yang melibatkan aspek kebebasan ruang awam, bidang kuasa tentera dan institusi badan kehakiman. Secara dasarnya, Perlembagaan Turki digubal sebagai manifestasi untuk memperkukuhkan autoriti serta keselamatan negara. Berasaskan premis "memelihara keselamatan negara," MGK cuba mencuri peluang bagi mendominasi ruang yang ada di dalam perlembagaan melalui pengukuhan kuasa sepertimana yang termaktub di dalam perlembagaan. Hal ini bertepatan seperti yang dijelaskan oleh Ümit Cizre Sakallioğlu, di mana tentera yang berpegang kepada doktrin "memelihara keselamatan negara" mempunyai kecenderungan untuk terlibat secara langsung di dalam ruang politik, termasuklah dengan mempengaruhi keputusan-keputusan kerajaan. ${ }^{20}$

Jadual 1: Premis Penggubalan Perlembagaan Era Turki Moden

\begin{tabular}{|l|l|}
\hline Perlembagaan & Premis penggubalan \\
\hline 1921 & Sebagai kerangka asas kepada kerajaan baharu yang ditubuhkan di Ankara \\
\hline 1924 & $\begin{array}{l}\text { Menggantikan sistem dwi-perundangan; sebagai kerangka asas penubuhan } \\
\text { negara Republik Turki }\end{array}$ \\
\hline 1961 & $\begin{array}{l}\text { Menangani "autoritarianisme"; memperkasakan hak asasi dan cabang } \\
\text { kehakiman }\end{array}$ \\
\hline 1982 & $\begin{array}{l}\text { Memperkasakan doktrin "memelihara keselamatan negara"; berperanan } \\
\text { sebagai entiti pengawal (tutelage entity) }\end{array}$ \\
\hline
\end{tabular}

Versi asal Perlembagaan Turki memperuntukkan keahlian MGK perlu dianggotai secara majoritinya oleh anggota tentera, di mana saranan-saranan MGK selaku penasihat kepada Majlis Menteri adalah menjadi keutamaan. Peruntukan ini menjadikan sebarang keputusan atau cadangan yang dikemukakan oleh pihak tentera kepada jemaah menteri sebagai pemutus, khususnya dalam aspek keselamatan negara. Pada masa yang sama, angkatan tentera Turki turut menikmati autonomi melalui Artikel 35 Kanun Perkhidmatan Luar Tentera Turki yang membolehkan tentera melakukan sebarang tindakan berasaskan justifikasi memelihara keamanan dan kestabilan negara. Profesor dan pakar perundangan Turki; Ergun Özbudun mengkritik Perlembagaan Turki kerana terlalu menumpukan kepada aspek keselamatan negara sehingga penjaminan hak dan kebebasan rakyat kurang ditekankan. ${ }^{21}$ Kesangsian tentera terhadap kegiatan politik sivil menyebabkan wujudnya keterbatasan ruang yang diperuntukkan untuk masyarakat awam. Misalnya, pertubuhan-pertubuhan sosial selain parti politik dilarang untuk menunjukkan atau menerima sokongan, mendanai serta terlibat dengan kegiatan parti-parti politik. Hal ini bertujuan supaya tentera dapat membataskan pengaruh parti-parti politik dengan menghalang akses entiti-entiti sivil lain dengan parti politik. ${ }^{22}$ Keterbatasan dalam berkegiatan bukan sahaja dikenakan kepada pertubuhan-pertubuhan sosial, malah turut melibatkan parti-parti politik. Sejak Perlembagaan Turki berkuat kuasa pada tahun 1982, Mahkamah Perlembagaan telah membubarkan sebanyak 19 buah parti politik serta mengenakan larangan berpolitik kepada beberapa tokoh dan pimpinan politik.

\footnotetext{
Menteri Dalam Negeri, Ketua Umum TSK, Komander Tentera Darat, Tentera Laut dan Tentera Udara. Untuk mengetahui lebih lanjut mengenai hal ehwal MGK, lihat laman sesawang rasmi MGK di Republic of Turkey Secretariat-General of the National Security Council, dicapai 7 November 2020, https://www.mgk.gov.tr/en/index.php.

${ }^{19}$ Paul Kubicek (2005), “The European Union and Grassroots Democratization in Turkey,” Turkish Studies, Jil. 6, Bil. 3, h. 364-365; Özbudun (2012), "Turkey's Search for a New Constitution," h. 40-41.

${ }^{20}$ Ümit Cizre Sakallioğlu (1997), “The Anatomy of the Turkish Military’s Political Autonomy,” Comparative Politics, Jil. 29, Bil.2, h. 152.

${ }^{21}$ Ergun Özbudun (2007), "Democratization Reforms in Turkey, 1993-2004," Turkish Studies, Jil. 8, Bil. 2, h. 180.

22 Özbudun (2012), “Turkey's Search for a New Constitution,” h. 41.
} 
Selain terlalu mengutamakan doktrin keselamatan negara, Perlembagaan Turki yang terbaharu turut memperlihatkan ciri-ciri sekularnya secara lebih keras berbanding perlembagaan-perlembagaan sebelumnya. Dalam hal ini, Artikel 1, 2 dan 3 Perlembagaan Turki telah memperuntukkan beberapa perkara yang menjadi asas utama Republik Turki. Manakala Artikel 4 pula menjelaskan bahawa ketigatiga artikel tersebut tidak boleh dipinda oleh sebarang pindaan. ${ }^{23}$ Ini bermaksud, identiti negara Turki sebagai sebuah republik (Artikel 1), negara Turki sebagai sebuah negara demokrasi dan sekular berasaskan konsep kedaulatan undang-undang dan semangat nasionalisme Atatürk (Artikel 2) serta Bahasa Turki sebagai bahasa kebangsaan serta perihal bendera kebangsaan, lagu kebangsaan dan Ankara sebagai ibu negara (Artikel 3) merupakan peruntukan-peruntukan yang tidak boleh diubah walau dengan apa cara sekalipun. Keberadaan Artikel 2 yang memperuntukkan dasar sekularisme sering menimbulkan ketegangan dan polemik, khususnya melibatkan isu-isu sensitiviti agama. Walaupun secara zahirnya kesemua rakyat Turki dijamin akan kebebasan dan kesamarataan di bawah perlembagaan (Artikel 10), tetapi kekangan kebebasan yang melibatkan sensitiviti agama tetap wujud. Misalnya pada tahun 2008, isu larangan pemakaian tudung untuk pelajar universiti telah cuba diangkat oleh AKP di palimen. Majoriti ahli parlimen bersetuju untuk meminda perlembagaan bagi membatalkan larangan tersebut supaya hak pelajar yang memakai tudung untuk mendapatkan pendidikan di universiti dapat dijamin sepertimana yang diperuntukkan di dalam Artikel 10 dan Artikel 42. Walau bagaimanapun, usul tersebut dibatalkan di peringkat Mahkamah Perlembagaan kerana dilihat mencabar prinsip sekularisme seperti yang termaktub di dalam Artikel 2 Perlembagaan Turki. ${ }^{24}$

Di samping itu, Perlembagaan Turki turut memperuntukkan kuasa yang luas kepada badan kehakiman. Dalam konteks struktur kehakiman di Turki, wujudnya dua badan kehakiman tertinggi iaitu Mahkamah Perlembagaan dan Badan Agung Pendakwa Raya dan Hakim (Hakimler ve Savcılar Yüksek Kurulu, HSYK). Menurut Mohammad Redzuan dan Mashitah Sulaiman, badan kehakiman tertinggi Turki, khususnya Mahkamah Perlembagaan dianggotai secara dominan oleh sekumpulan kecil elit tentera. ${ }^{25}$ Maka, tidak hairanlah mengapa melalui Mahkamah Perlembagaan, beberapa parti pro-Islam telah diharamkan di atas alasan "menjadi pusat kepada kegiatan anti-sekular." Dalam hal ini, Artikel 69 di dalam Perlembagaan Turki sering menjadi rujukan oleh pihak mahkamah untuk mengharamkan partiparti politik yang dilihat mencabar kedudukan sekularisme. Artikel tersebut antaranya menyatakan bahawa Mahkamah Perlembagaan mempunyai kuasa untuk membubarkan mana-mana parti politik yang dilihat menyalahi perenggan keempat Artikel 68, iaitu:

Statut, program serta aktiviti parti-parti politik tidak boleh bertentangan dengan aspirasi kemerdekaan negara, nilai integriti yang tidak dipisahkan dengan wilayah dan negara, hak asasi manusia, prinsip kesetaraan dan kedaulatan undang-undang, kedaulatan negara, prinsip-prinsip demokratik dan sekular republik; tidak menggalakkan sebarang unsur kediktatoran dan tidak menghasut rakyat untuk melakukan jenayah. ${ }^{26}$

Dengan ini, Artikel 69 memberikan Mahkamah Perlembagaan kuasa yang mutlak dalam menentukan kelangsungan parti-parti politik di Turki. Tambahan pula, walaupun peruntukan-peruntukan di dalam Perlembagaan Turki dilihat memperkukuhkan kedudukan sayap kehakiman sebagai entiti yang bebas, tetapi kuasanya yang luas menyebabkan institusi kehakiman mempunyai kecenderungan yang kuat untuk menjadikan Turki sebagai sebuah negara berasaskan "juristokrasi."27

\section{Pindaan Perlembagaan Turki sebagai Inisiatif Pendemokrasian}

Bagi mengukuhkan pentadbiran dan mewujudkan suasana demokrasi yang lebih sihat, AKP telah mengambil langkah mengusulkan pindaan terhadap Perlembagaan Turki yang melibatkan beberapa artikel. Insiatif bagi meminda Perlembagaan Turki bermula pada 30 Mac 2010, bilamana AKP telah mengusulkan pakej reformasi ke parlimen. Pada penghujung April, pakej yang diusulkan telah menerima kelulusan untuk dibuat undian di peringkat parlimen. Untuk sesuatu usul itu diterima dan

\footnotetext{
${ }^{23}$ Untuk terjemahan Bahasa Inggeris bagi Perlembagaan Turki 1982, lihat Constitution of the Republic Turkey (1982), Egemenlik Kayitsiz Şatsiz Milletindir.

${ }^{24}$ Ayse Saktanber dan Gül Çorbacioğlu (2008), "Veiling and Headscarf-Skepticism in Turkey,” Social Politics, Jil. 15, Bil. 4, h. 514-515.

${ }^{25}$ Mohammad Redzuan Othman dan Mashitah Sulaiman (2015), Sekularisme dan Proses Demokrasi di Turki: Pemerkasaan Islam dan Kepimpinan Erdogan, Kuala Lumpur: Penerbit Universiti Malaya, h. 114.

${ }^{26}$ Article 68 Constitution of the Republic Turkey, 30.

${ }^{27}$ Özbudun (2012), "Turkey's Search for a New Constitution," h. 49. Polemik “juristokrasi” menggambarkan sayap kehakiman yang sangat berpengaruh dalam menentukan perjalanan pentadbiran di Turki.
} 
dilaksanakan secara terus, usul tersebut perlu mendapat sokongan minimum majoriti dua pertiga undi, iaitu bersamaan sokongan 367 daripada 550 ahli parlimen. Namun, usul pindaan yang dikemukakan hanya memperoleh sokongan sebanyak tiga perlima undi sahaja, menyebabkan pakej pindaan tersebut tidak dapat dilaksanakan secara terus. Walau bagaimanapun, undi yang diperolehi adalah memadai bagi dikemukakan kepada Presiden untuk dipertimbangkan sama ada akan diserahkan semula kepada parlimen untuk dibahaskan secara lebih terperinci atau dilakukan referendum di peringkat nasional. ${ }^{28}$ Pada 13 Mei 2010, Presiden Turki Ketika itu; Abdullah Gül telah menandatangani pakej pindaan tersebut dan bersetuju supaya diadakan referendum di peringkat nasional pada 12 September 2010.

Referendum yang dijalankan telah menjadi medan pertembungan antara kelompok yang menyokong dan yang menolak pakej pindaan tersebut. Dua parti pembangkang utama, iaitu CHP dan Parti Gerakan Nasionalis (Milliyetçi Hareket Partisi, MHP) mengambil kesempatan sepanjang kempen referendum untuk menggoyahkan keyakinan rakyat terhadap kepimpinan kerajaan di bawah AKP. ${ }^{29}$ CHP mendakwa bahawa AKP cuba untuk mengambil alih kesemua institusi negara, termasuklah institusi kehakiman, dan cenderung untuk memerintah secara mutlak jika pindaan perlembagaan berjaya dilaksanakan. ${ }^{30}$ Manakala MHP pula menggunakan retorik kebangsaan dengan mendakwa referendum yang dijalankan sebagai ejen pemecah-belah negara dan perlu ditolak oleh rakyat.

Walau bagaimanapun, AKP menafikan dakwaan-dakwaan seteru politiknya dengan menghujahkan bahawa pakej pindaan perlembagaan yang dikemukakan adalah bertujuan menjunjung aspirasi demokrasi yang sebenarnya dan mewujudkan "negara Turki baharu" yang tidak lagi berimejkan junta tentera. ${ }^{31}$ Dalam referendum tersebut, rakyat diberi pilihan bagi memilih secara pakej sama ada bersetuju dengan usul pindaan secara keseluruhan dengan mengundi "Ya" atau tidak bersetuju dengan mengundi "Tidak." Keputusan referendum yang diadakan pada 12 September 2010 itu memperlihatkan daripada 73.71 peratus rakyat Turki yang turun mengundi, 57.88 peratus memilih "Ya", manakala 42.12 peratus lagi memilih "Tidak." Keputusan tersebut memberi laluan kepada pelaksanaan pakej pindaan perlembagaan seperti yang dicadangkan.

Jadual 2: Keputusan Keseluruhan Referendum Nasional 12 September 2010

\begin{tabular}{|lll|}
\hline Undian & Bilangan pengundi & Peratus (\%) \\
\hline "Ya" & $21,788,272$ & 57.88 \\
"Tidak" & $15,855,041$ & 42.12 \\
Perangkaan keseluruhan & & \\
\hline Bilangan turun mengundi & $52,051,828$ & \\
Peratusan turun mengundi (\%) & 73.71 & \\
Jumlah undian yang sah & $37,643,313$ & \\
\hline
\end{tabular}

Sumber: Turkey's September 12, 2010, Referendum ${ }^{32}$

Keputusan referendum tersebut boleh dianalisis dan diperhalusi berdasarkan beberapa sudut. Pertama, keputusan referendum memperlihatkan kejayaan AKP dalam meyakinkan rakyat Turki untuk mengundi "Ya." Sepanjang kempen referendum 12 September, parti-parti utama di Turki telah memanfaatkan referendum tersebut sebagai medan untuk meninjau kecenderungan atau tahap sokongan rakyat terhadap mereka. AKP selaku pihak yang mengemukakan pakej pindaan perlembagaan mewakili premis "Ya" dalam referendum berkenaan. Maka, 57.88 peratus, atau bersamaan 21,788,272 rakyat Turki yang memilih "Ya" boleh disimpulkan sebagai simbolik terhadap undian sokongan bukan sahaja terhadap pakej pindaan perlembagaan, malah juga terhadap kerajaan AKP secara tidak langsung. ${ }^{33}$ Dalam pilihan raya umum 2007, AKP memperoleh sekitar 47 peratus undi popular rakyat. Jika 47 peratus pengundi yang mengundi AKP mengekalkan sokongan kepada AKP dengan mengundi "Ya"

28 Sinan Ciddi (2011), “Turkey's September 12, 2010, Referendum,” Rubin Center, dicapai 14 Oktober 2017, http://www.rubincenter.org/2011/12/turkey\%E2\%80\%99s-september-12-2010-referendum/.

${ }^{29}$ Hatem Ete, Nuh Y1lmaz dan Kadir Üstün (2011), "Turkey’s Constitutional Referendum of 2010 and Insights for The General Elections of 2011," Seta Policy Report, h. 7; Jonathan Head (2010), "Referendum result fails to mask Turkey's divisions," BBC News, dicapai 4 Januari 2018, http://www.bbc.com/news/world-europe-11288360.

${ }^{30}$ Dietrich Jung (2010), The Constitutional Referendum in Turkey: A Step Toward Democracy?, Odense: Center for Mellemøststudier, Syddansk Universitet, h. 2.

${ }^{31}$ Ete, Y1lmaz dan Üstün (2011), “Turkey's Constitutional Referendum of 2010,” h. 8-11.

${ }^{32}$ Ciddi (2011), "Turkey's September 12, 2010, Referendum".

${ }^{33}$ Al Jazeera Centre for Studies (2010), Implications of the Turkish Referendum on Constitutional Amendments, Doha: Al Jazeera Network, h. 5 . 
semasa referendum nasional, ini bermaksud hampir 11 peratus pengundi yang berbaki (daripada kirakira 58 peratus rakyat yang mengundi "Ya") merupakan pemilih yang turut memihak kepada pindaan, namun tidak mengundi AKP dalam pilihan raya umum sebelumnya. Hal ini menunjukkan bahawa inisiatif pendemokrasian AKP telah berjaya meyakinkan masyarakat Turki sehinggakan AKP berupaya meraih sokongan luar daripada mereka yang menyokongnya sebelum ini. ${ }^{34}$

Kedua, referendum 12 September turut memperlihatkan kegagalan kempen parti-parti pembangkang utama, khususnya CHP dan MHP, untuk menggoyahkan kepercayaan rakyat terhadap inisiatif pendemokrasian AKP. Dalam referendum tersebut, CHP dan MHP yang mewakili premis "Tidak" menggunakan hujah yang berbeza. Sepanjang kempen, CHP dilihat kurang memberi perhatian terhadap isi pakej pindaan perlembagaan. Sebaliknya, mereka terlalu memfokuskan kepada sisi kelemahan pemerintahan AKP semata-mata. ${ }^{35}$ Walaupun CHP merupakan parti beraspirasikan idea Kemalisme, imej tersebut didapati tidak berupaya memberikan merit kepada CHP. Malah, CHP yang menolak pakej pindaan perlembagaan turut dilihat bersama autoritarianisme tentera dan menolak agenda pendemokrasian yang merupakan permintaan popular rakyat Turki. ${ }^{36} \mathrm{Hal}$ ini menyebabkan aspirasi CHP bagi menolak pakej pindaan perlembagaan yang dicadangkan oleh AKP tidak disambut oleh rakyat Turki semasa pengundian referendum. Manakala MHP yang berpaksikan kepada retorik kebangsaan pula dilihat tidak berjaya untuk meyakinkan rakyat Turki mengenai "elemen pemisah" yang terkandung di dalam pakej pindaan perlembagaan tersebut. Walaupun MHP tidak menggunakan hujah ideologi sepertimana CHP, MHP juga tidak berjaya untuk mempengaruhi kehendak popular rakyat yang menginginkan perubahan terhadap demokrasi di Turki.

Ketiga, keputusan referendum juga boleh dilihat berdasarkan keputusan undian mengikut kawasan atau wilayah. Rajah 1 di bawah merupakan keputusan referendum mengikut kawasan-kawasan di seluruh Turki. Jika diteliti, kawasan-kawasan di mana pakej pindaan perlembagaan tidak memperoleh sokongan melebihi 50 peratus terletak di sekitar persisiran Thracia, Laut Aegean dan Laut Mediterranean. Kawasan-kawasan ini merupakan kawasan kubu kuat pendokong sekular dan sekaligus merupakan kawasan tradisi CHP. ${ }^{37}$ Manakala majoriti pengundi di kawasan selebihnya yang merangkumi pusat Anatolia sehingga persisiran Laut Hitam mengundi "Ya" semasa referendum, kecuali Tunceli yang merupakan kubu kuat pendokong beraliran tengah-kiri (centre-left). ${ }^{38}$ Selain itu, kawasan tenggara Turki yang majoriti penduduknya berbangsa Kurdi turut memihak kepada pakej pindaan perlembagaan. Walaupun parti-parti yang mewakili masyarakat Kurdi menolak dan memboikot pakej pindaan perlembagaan kerana melihat ia tidak mengambil kira kepentingan masyarakat Kurdi, ${ }^{39}$ keputusan referendum memperlihatkan pengundi di kawasan tersebut cenderung untuk memihak kepada pakej berkenaan meskipun peratusan turun mengundi di kawasan tersebut tidak tinggi seperti kawasankawasan yang lain.

\section{Rajah 1: Keputusan Referendum 12 September 2010 Mengikut Kawasan*}

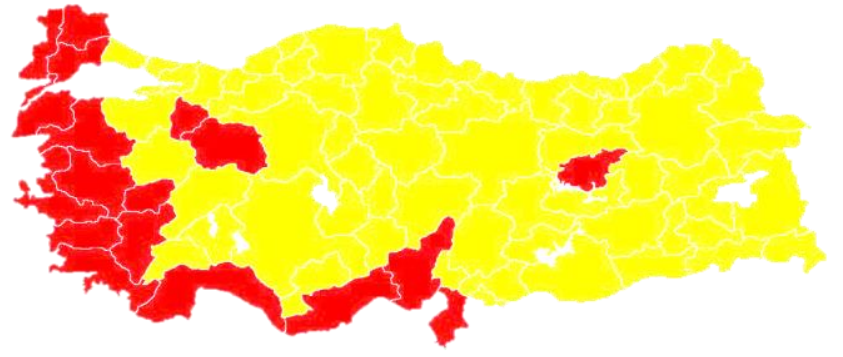

*kuning: majoriti pengundi memilih "Ya"; merah: majoriti pengundi memilih "Tidak" Sumber: FPC Briefing: Analysing Turkey's 2010 constitutional referendum ${ }^{40}$

\footnotetext{
${ }^{34}$ Ete, Y1lmaz dan Üstün (2011), “Turkey’s Constitutional Referendum of 2010,” h. 10.

${ }^{35}$ Ete, Y1lmaz dan Üstün (2011), "Turkey's Constitutional Referendum of 2010," h. 13-14; Jonathan (2010), "Referendum result fails to mask Turkey's divisions.”

${ }^{36}$ Ete, Y1lmaz dan Üstün (2011), “Turkey’s Constitutional Referendum of 2010,” 8.

${ }^{37}$ Marc Herzog (2010), FPC Briefing: Analysing Turkey's 2010 Constitutional Referendum, London: The Foreign Policy Centre, h. 3.

${ }^{38}$ Herzog (2010), FPC Briefing, h. 3.

${ }^{39}$ Redzuan dan Mashitah (2015), Sekularisme dan Proses Demokrasi di Turki, h. 111; Ete, Y1lmaz dan Üstün (2011), “Turkey’s Constitutional Referendum of 2010," h. 11.

${ }^{40}$ Herzog (2010), FPC Briefing, h. 3.
} 
Walaupun sepanjang kempen referendum memperlihatkan pertembungan yang dingin berlaku antara pimpinan dan pendokong parti-parti utama, keputusan referendum 12 September menunjukkan bahawa sebahagian besar rakyat mengimpikan perubahan buat negara Turki ke arah yang lebih demokratik. Selain itu, referendum tersebut juga menggambarkan bahawa rakyat Turki tidak lagi cenderung terhadap sesebuah entiti khusus, sebaliknya lebih cenderung kepada agenda yang dibawa khususnya terhadap agenda pendemokrasian. Dalam hal ini, AKP dilihat berjaya menjunjung agenda tersebut yang sekaligus memberikannya kemenangan dalam referendum berkenaan. Keputusan referendum yang memihak kepada pakej pindaan perlembagaan memberi peluang bagi pindaan terhadap Perlembagaan Turki dikuat kuasakan secara rasmi bermula pada 23 September 2010.

\section{Intipati Pindaan Perlembagaan}

Secara asasnya, artikel-artikel yang dipinda melalui pindaan perlembagaan tahun 2010 melibatkan artikel sementara (provisional articles) dan artikel biasa. Artikel sementara merupakan artikel di dalam Perlembagaan Turki yang penguat kuasaannya adalah terhad bagi tempoh-tempoh tertentu. Secara lazimnya, artikel sementara memperincikan perkara-perkara tertentu di dalam artikel biasa yang berfungsi secara sementara selagimana artikel-artikel biasa yang diperincikan berfungsi seperti asal dan tidak mengalami pindaan. Untuk pindaan perlembagaan tahun 2010, satu artikel sementara telah dimansuhkan di samping dua artikel sementara yang telah ditambah.

i) Artikel sementara (yang dimansuhkan)

Artikel Sementara 15: Artikel ini memperincikan mengenai imuniti pada anggota MGK yang terlibat dan bertanggungjawab melakukan rampasan kuasa pada 12 September 1980. Merujuk kepada artikel ini, anggota MGK tersebut tidak boleh dikenakan sebarang tuduhan jenayah, tindakan undang-undang, denda berbentuk duit atau disabitkan sebagai melanggari perlembagaan disebabkan rampasan kuasa yang telah dijalankan. ${ }^{41}$ Pindaan perlembagaan tahun 2010 telah memansuhkan Artikel Sementara 15 ini.

\section{ii) Artikel sementara (yang ditambah)}

Artikel Sementara 18: Artikel ini memperincikan mengenai keanggotaan baharu bagi Mahkamah Perlembagaan selepas pindaan perlembagaan yang dilaksanakan. Perinciannya merangkumi tatacara pemilihan keanggotaan, pelaksanaan gerak kerja dan tempoh penjawatan bagi ahli Mahkamah Perlembagaan. ${ }^{42}$ Secara keseluruhannya, Artikel Sementara 18 ini memperincikan kandungan bagi Artikel 146 dan Artikel 147 di dalam artikel biasa Perlembagaan Turki yang memperihalkan mengenai pembentukan Mahkamah Perlembagaan.

Artikel Sementara 19: Artikel ini memperincikan mengenai keanggotaan baharu bagi HSYK selepas pindaan perlembagaan yang dilaksanakan. Perinciannya merangkumi tatacara pemilihan keanggotaan, pelaksanaan gerak kerja dan tempoh penjawatan bagi ahli HSYK. ${ }^{43}$ Untuk Artikel Sementara 19 pula, secara umumnya ia berfungsi bagi memperincikan kandungan Artikel 159 di dalam artikel biasa Perlembagaan Turki yang memperihalkan mengenai penstrukturan HSYK.

Artikel biasa pula merupakan artikel-artikel utama yang membentuk Perlembagaan Turki. Pakej pindaan perlembagaan tahun 2010 yang dicadangkan oleh AKP pada asalnya melibatkan pindaanpindaan yang memberi kesan terhadap 24 artikel di dalam Perlembagaan Turki. Setiap artikel memerlukan sekurang-kurangnya 330 undi di peringkat parlimen bagi kedua-dua pusingan undian untuk diluluskan sebagai referendum. Kesemua artikel tersebut berjaya memperoleh undi minimum, kecuali bagi Artikel 69 yang memperuntukkan kuasa kepada Mahkamah Perlembagaan untuk membubarkan parti-parti politik. Walaupun pindaan bagi Artikel 69 berjaya memperoleh undi minimum dalam undian pusingan pertama, namun artikel tersebut hanya memperoleh sebanyak 327 undian dalam pusingan kedua. Hal ini menyebabkan Artikel 69 terpaksa digugurkan dari pakej pindaan perlembagaan yang dicadangkan. ${ }^{44}$ Secara keseluruhannya, pakej pindaan perlembagaan tahun 2010 melibatkan 23 artikel yang boleh dipecahkan kepada beberapa kategori. Penulis membahagikan pindaan-pindaan tersebut kepada kategori-kategori sepertimana pengkategorian yang dibuat di dalam

\footnotetext{
41 "Provisional Article 15 Constitution of Republic Turkey."

${ }^{42}$ Provisional Article 18 Constitution of Republic Turkey, h. 98-100.

${ }^{43}$ Provisional Article 19 Constitution of Republic Turkey, h. 100-104.

${ }^{44}$ Redzuan dan Mashitah (2015), Sekularisme dan Proses Demokrasi di Turki, h. 111.
} 
Perlembagaan Turki iaitu: i) peruntukan umum; ii) hak asasi dan peranan; iii) legislatif; iv) eksekutif; v) kehakiman; dan vi) peruntukan ekonomi.

\section{i) Peruntukan umum}

Artikel 10 (Kesaksamaan Undang-undang): Melalui pindaan tahun 2010, Artikel 10 dilengkapkan dengan frasa: "Langkah-langkah yang diambil untuk tujuan ini [mengenai kesetaraan undang-undang dan peranan kerajaan untuk memastikan kesetaraan tersebut diamalkan] tidak boleh ditafsirkan sebagai bertentangan dengan prinsip kesaksamaan" serta perenggan baharu: "Langkah-langkah yang diambil untuk kanak-kanak, orang tua, orang kurang upaya, ibu tunggal dan anak-anak yatim yang bapanya terkorban di dalam peperangan serta golongan yang kurang berkemampuan dan veteran tidak boleh dianggap sebagai melanggar prinsip kesaksamaan." ${ }^{45}$

\section{ii) Hak asasi dan peranan}

Artikel 20 (Privasi Perseorangan): Pindaan tahun 2010 menambah peruntukan berhubung hak pemeliharaan data persendirian atau maklumat peribadi untuk semua. Rakyat juga berhak untuk dimaklumkan, mengakses, meminta pembetulan dibuat serta penghapusan akan data persendiriannya. Data yang diproses juga perlu mendapatkan persetujuan pemilik data terlebih dahulu. ${ }^{46}$

Artikel 23 (Kebebasan untuk Menetap dan Berhijrah): Pindaan yang dibuat pada tahun 2001 menyatakan larangan terhadap seseorang untuk meninggalkan negara akan dikenakan sekiranya terdapat tanggungjawab sivik, siasatan jenayah atau pendakwaan. ${ }^{47}$ Pindaan tahun 2010 pula menghilangkan frasa "tanggungjawab sivik" pada perenggan berkenaan dan menetapkan larangan meninggalkan negara hanya terangkum di bawah siasatan jenayah atau pendakwaan sahaja. ${ }^{48}$

Artikel 41 (Pelindungan Keluarga dan Hak Kanak-kanak): ${ }^{49}$ Dua perenggan baharu ditambah dalam Artikel 41 dengan memberi jaminan hak kepada setiap kanak-kanak untuk diberikan keselamatan dan perlindungan serta hak untuk mengekalkan hubungan dengan ibu bapanya, melainkan jika bertentangan dengan kehendak kanak-kanak tersebut. Selain itu, kerajaan juga bertanggungjawab untuk mengambil langkah melindungi kanak-kanak dari sebarang penyalahgunaan dan keganasan. ${ }^{50}$

Artikel 51 (Hak Menguruskan Pertubuhan): Pindaan pada tahun 2010 memansuhkan perenggan yang melarang majikan dan pekerja untuk menganggotai lebih dari sebuah kesatuan sekerja. ${ }^{51}$

Artikel 53 (Hak Mengadakan Perjanjian bagi Pekerja dan Perjanjian Secara Berkumpulan): Pindaan tahun 2010 menambah frasa "Perjanjian Secara Berkumpulan" di dalam tajuk bagi Artikel 53 di samping menambah beberapa perenggan baharu yang boleh dirumuskan seperti berikut: i) pemberian hak kepada penjawat awam dan pekerja-pekerja dalam sektor lain untuk membuat perjanjian secara berkumpulan; dan ii) mereka yang mengadakan perjanjian secara berkumpulan boleh merujuk kepada Lembaga Pertimbangan Awam jika terdapat sebarang bantahan terhadap perjanjian yang dilakukan, di mana keputusan lembaga tersebut akan menjadi keputusan yang muktamad. ${ }^{52}$

Artikel 54 (Hak untuk Protes dan Mogok): Perenggan yang memperuntukkan mengenai tanggungjawab kesatuan pekerja terhadap sebarang kerosakan harta benda yang berada di lokasi protes diadakan dimansuhkan melalui pindaan tahun 2010. Perenggan yang menjelaskan mengenai larangan bagi sebarang protes dan mogok yang bermotifkan politik turut dimansuhkan. ${ }^{53}$

Artikel 74 (Hak Untuk Berpetisyen, Maklumat dan Pemohonan Melalui Ombudsman): Pindaan tahun 2010 telah menambah peruntukan baharu kepada penubuhan Ombudsman. Frasa "[hak untuk memperoleh] Maklumat dan Pemohonan Melalui Ombudsman" telah dimasukkan ke dalam tajuk bagi

\footnotetext{
${ }^{45}$ Article 10 Constitution of Republic Turkey, h. 4.

${ }^{46}$ Article 20 Constitution of Republic Turkey, h. 10

${ }^{47}$ Levent Gönenç (2004), "The 2001 Amendments to the 1982 Constitution of Turkey," Ankara Law Review, Jil. 1, Bil. 1, h. 102.

${ }^{48}$ Article 23 Constitution of Republic Turkey, h. 11.

${ }^{49}$ Frasa "Hak Kanak-kanak" telah ditambah pada tajuk Artikel 41 melalui pindaan perlembagaan tahun 2010.

${ }^{50}$ Article 41 Constitution of Republic Turkey, h. 19.

${ }^{51}$ Article 51 Constitution of Republic Turkey, h. 24

${ }^{52}$ Article 53 Constitution of Republic Turkey, h. 24-25.

${ }^{53}$ Article 54 Constitution of Republic Turkey, h. 25.
} 
Artikel 74. Struktur Ombudsman turut diperincikan di dalam perenggan baharu yang ditambah ke dalam artikel berkenaan. ${ }^{54}$

\section{iii) Legislatif}

Artikel 84 (Pengguguran Keahlian): Artikel ini memperihalkan mengenai status keahlian parlimen. Perenggan yang menyatakan berhubung pengguguran keahlian seseorang ahli parlimen jika parti yang diwakilinya dibubarkan oleh Mahkamah Perlembagaan dimansuhkan melalui pindaan tahun 2010. Ini menjadikan pengharaman sesebuah parti politik tidak menjejaskan kedudukan ahli parlimen dari parti tersebut. ${ }^{55}$

Artikel 94 (Biro Parlimen): Perenggan baharu telah ditambah di dalam Artikel 94 yang menyebutkan: "Dua kali pemilihan untuk memilih biro parlimen akan diadakan untuk satu penggal legislatif. Biro yang dipilih dalam pemilihan pertama akan berfungsi selama dua tahun dan diikuti pemilihan kedua yang akan berfungsi sehingga parlimen bagi penggal tersebut dibubarkan."${ }^{, 56}$

\section{iv) Eksekutif}

Artikel 125 (Semakan Kehakiman): Pindaan terhadap Artikel 125 adalah mengenai pemerkasaan undang-undang dengan memperluaskan proses semakan kehakiman terhadap pentadbiran eksekutif. Perenggan kedua artikel berkenaan yang asal mencatatkan bahawa: "Tindakan Presiden serta keputusan Majlis Tertinggi Tentera adalah di luar dari skop semakan kehakiman." Melalui pindaan tahun 2010, perenggan tersebut telah ditambah dengan peruntukan baharu yang membolehkan keputusan Majlis Tertinggi Tentera tertakluk di bawah semakan kehakiman. ${ }^{57}$

Artikel 128 (Prinsip Umum bagi Peruntukan Penjawat Awam): Pindaan pada Artikel 128 hampir sama dengan pindaan yang dilakukan pada Artikel 53, iaitu melibatkan keizinan penjawat awam untuk melakukan perjanjian secara berkumpulan yang melibatkan hal ehwal kewangan dan hak asasi. Penambahan telah dilakukan terhadap perenggan pertama Artikel 128 berdasarkan peruntukan tersebut. ${ }^{58}$

Artikel 129 (Peranan, Tanggungjawab dan Jaminan bagi Prodising Tatatertib): Melalui peruntukan sebelumnya, penjawat awam yang dikenakan tindakan disiplin tertakluk di bawah semakan kehakiman kecuali bagi kes amaran atau teguran. Pindaan tahun 2010 memansuhkan pengecualian tersebut. ${ }^{59}$

\section{v) Kehakiman}

Artikel 144 (Penyeliaan Perkhidmatan Kehakiman): Pindaan tahun 2010 mengubah hampir keseluruhan perenggan di dalam Artikel 144. Selepas pindaan, artikel berkenaan menyebutkan bahawa: "Penyeliaan perkhidmatan kehakiman serta pendakwa raya awam yang melibatkan bidang kuasa mereka perlulah dilakukan oleh Kementerian Keadilan melalui pemeriksa kehakiman dan juruaudit dalaman yang berlatar belakangkan bidang kehakiman dan pendakwa raya awam, di samping penyiasatan dan pemeriksaan juga perlulah melalui pemeriksa kehakiman. Langkah-langkah dan prinsip yang diambil perlulah selari dengan undang-undang." ${ }^{60}$

Artikel 145 (Keadilan Tentera): Artikel 145 memperuntukkan mengenai mahkamah bagi mengadili pegawai tentera. Pindaan tahun 2010 telah menambah frasa pada perenggan pertama di mana bagi keskes yang melibatkan selain dari hal ehwal ketenteraan, pegawai itu perlulah diadili di mahkamah sivil atau awam. Selain itu, frasa baharu turut ditambah yang membentuk perenggan kedua dengan menyebut: "Mereka yang selain tentera tidak boleh disoal siasat di mahkamah tentera melainkan semasa peperangan." 61

\footnotetext{
${ }^{54}$ Untuk perbincangan lebih lanjut mengenai struktur dan fungsi Ombudsman di Turki, lihat H. Alpay Karasoy (2015), "Ombudsman in Turkey: Its Contributions and Criticism," European Scientific Journal, Jil. 11, Bil. 22, h. 46-59.

${ }^{55}$ Article 84 Constitution of Republic Turkey, h. 39.

${ }^{56}$ Memandangkan tempoh bagi satu penggal legislatif telah dipendekkan dari lima tahun kepada empat tahun melalui pindaan perlembagaan pada tahun 2007, maka secara lazimnya biro parlimen yang dipilih melalui pemilihan kedua juga akan berfungsi selama dua tahun. Lihat Levent Gönenç (2010), "2010 Proposed Constitutional Amendments to the 1982 Constitution of Turkey," TEPAV Evaluation Note, h. 3.

${ }^{57}$ Gönenç (2010), “2010 Proposed Constitutional Amendments to the 1982 Constitution of Turkey,” h. 4.

${ }^{58}$ Article 128 Constitution of Republic Turkey, h. 64.

${ }^{59}$ Article 129 Constitution of Republic Turkey, h. 64.

${ }^{60}$ Article 144 Constitution of Republic Turkey, h. 72.

${ }^{61}$ Article 145 Constitution of Republic Turkey, h. 72.
} 
Artikel 146 (Mahkamah Perlembagaan: Pembentukan): Pindaan tahun 2010 menambah keahlian Mahkamah Perlembagaan daripada 11 orang ahli tetap dan empat orang ahli tambahan kepada 17 ahli tetap. Pemilihannya juga turut diperincikan di mana parlimen berhak memilih tiga orang ahli, manakala Presiden berkuasa untuk memilih anggota selebihnya dari mahkamah tinggi, Dewan Negara dan YÖK. ${ }^{62}$

Artikel 147 (Mahkamah Perlembagaan: Tempoh Keahlian dan Penyingkiran): Pindaan dibuat pada perenggan pertama mengenai tempoh keahlian bagi yang menganggotai Mahkamah Perlembagaan, di mana had umur 65 tahun dikekalkan di samping menambah frasa: “...dipilih untuk menganggotai bagi tempoh 12 tahun." Manakala mereka yang pernah berada di dalam organisasi Mahkamah Perlembagaan tidak boleh dipilih lagi bagi sesi-sesi seterusnya. ${ }^{63}$

Artikel 148 (Mahkamah Perlembagaan: Fungsi dan Kuasa): Artikel yang memperihalkan fungsi dan kuasa Mahkamah Perlembagaan ini mengalami perubahan terhadap sebahagian besar peruntukannya. Secara ringkasnya, pindaan terhadap Artikel 148 dapat dirumuskan sebagaimana yang berikut: i) pemberian hak kepada semua untuk membuat aduan secara langsung di Mahkamah Perlembagaan yang melibatkan pencabulan hak asasi dan kebebasan; ii) Mahkamah Perlembagaan di atas kapasitinya sebagai mahkamah agung mempunyai kuasa untuk mengadili Presiden Turki, speaker parlimen, ahli kabinet menteri, anggota-anggota Mahkamah Perlembagaan, Mahkamah Tinggi Rayuan, Dewan Negara, Mahkamah Tinggi Rayuan Tentera, Mahkamah Pentadbiran Tinggi Tentera, ahli HSYK, Ketua Pendakwa Raya Awam serta timbalannya; dan iii) Ketua Turus Angkatan Tentera, komander-komander angkatan tentera darat, laut dan udara serta Panglima Besar Gendarmerie juga boleh dibicarakan di Mahkamah Perlembagaan. ${ }^{64}$

Artikel 149 (Mahkamah Perlembagaan: Prosedur Fungsi dan Perbicaraan): Pindaan tahun 2010 telah meminda prosedur pengadilan Mahkamah Perlembagaan. Mahkamah Perlembagaan dalam peranannya untuk membatalkan sesuatu pindaan perlembagaan, memutuskan untuk membubarkan sesebuah parti politik atau pengurangan bantuan terhadap parti-parti politik perlulah memenuhi korum dua pertiga majoriti untuk memulakan proses pembicaraan. ${ }^{65}$

Artikel 156 (Mahkamah Tinggi Rayuan Tentera): Artikel yang mengkhususkan peruntukan kepada Mahkamah Tinggi Rayuan Tentera ini telah mengalami perubahan pada perenggannya yang keempat. Pindaan tahun 2010 telah memadamkan frasa "...berdasarkan keperluan khidmat tentera" pada perenggan tersebut yang menjelaskan mengenai prinsip pengorganisasian serta fungsi Mahkamah Tinggi Rayuan Tentera. ${ }^{66}$

Artikel 157 (Mahkamah Tinggi Pentadbiran Tentera): Artikel 157, iaitu yang mengkhususkan mengenai Mahkamah Tinggi Pentadbiran Tentera mengalami perubahan yang serupa sepertimana yang berlaku pada Artikel 156. Frasa “...berdasarkan keperluan khidmat tentera” telah dipadamkan pada perenggan terakhir artikel tersebut. ${ }^{67}$

Artikel 159 (HSYK): Artikel ini melibatkan penstrukturan HSYK. Pindaan tahun 2010 telah menambah keahlian badan kehakiman tersebut kepada 22 ahli tetap serta 12 ahli tambahan melalui penambahan perenggan kedua. Pemilihan ahli HSYK turut diperincikan. Selain itu, HSYK juga menjadi badan yang bebas di mana badan tersebut perlu mempunyai bajet dan kewangannya secara sendiri. ${ }^{68}$

\section{vi) Peruntukan ekonomi}

Artikel 166 (Perancangan: Majlis Ekonomi dan Sosial): Frasa "Majlis Ekonomi dan Sosial" pada tajuk Artikel 166 telah ditambah melalui pindaan tahun 2010. Artikel ini memperihalkan mengenai perancangan ekonomi, sosial dan pembangunan yang menjadi tanggungjawab kerajaan dalam membangunkan negara. Pindaan pada tahun 2010 telah menambah perenggan baharu di dalam Artikel

\footnotetext{
${ }^{62}$ Article 146 Constitution of Republic Turkey, h. 73-74.

${ }^{63}$ Article 147 Constitution of Republic Turkey, h. 75.

${ }^{64}$ Article 148 Constitution of Republic Turkey, h. 75-77.

${ }^{65}$ Article 149 Constitution of Republic Turkey, h. 77.

${ }^{66}$ Article 156 Constitution of Republic Turkey, h. 82.

${ }^{67}$ Article 157 Constitution of Republic Turkey, h. 82.

${ }^{68}$ Article 159 Constitution of Republic Turkey, h. 83-84.
} 
166 yang memperuntukkan supaya diwujudkan Majlis Ekonomi dan Sosial selaku badan yang berperanan memberikan saranan dan konsultasi kepada kerajaan berhubung polisi ekonomi dan sosial. ${ }^{69}$

\section{Kesan Pindaan Perlembagaan terhadap Perkembangan Demokrasi}

\section{Kesan kepada Pemerkasaan Hak Asasi}

Agenda pendemokrasian sememangnya menjadi tumpuan AKP dalam usaha mewujudkan negara Turki yang lebih demokratik dan liberal. ${ }^{70}$ Dalam memastikan suasana demokratik di Turki terus terjamin, aspek hak asasi, kebebasan ruang awam serta pemerkasaan proses demokrasi telah diberikan keutamaan. Pindaan yang dibuat pada Artikel 10 telah memperkukuhkan lagi konsep kedaulatan dan kesaksamaan undang-undang. Perenggan kedua artikel tersebut menyatakan mengenai kesetaraan hak lelaki dan wanita, dengan menambah peruntukan baharu iaitu: "Langkah-langkah yang diambil untuk tujuan memelihara kesetaraan tidak boleh ditafsirkan sebagai bertentangan dengan prinsip kesaksamaan." ${ }^{\text {"1 }}$ Pada tahun 2008, AKP telah berusaha untuk meminda Artikel 10 supaya kebebasan untuk pelajar universiti memakai tudung dapat diberikan. Namun, usaha tersebut menghadapi kebuntuan kerana dilihat sebagai menyanggahi prinsip sekularisme. Namun, peruntukan baharu selepas pindaan perlembagaan tahun 2010 dilihat menjamin kebebasan tersebut, di mana sebarang langkah yang boleh ditafsir sebagai "memelihara kesetaraan hak" tidak lagi menjadi suatu masalah. Hal ini membolehkan laluan kepada pemansuhan larangan bertudung di pelbagai peringkat berdasarkan hujah mereka yang bertudung juga perlu diberikan hak untuk ke sekolah, ke universiti dan berkhidmat di sektor awam sebagaimana masyarakat Turki yang lain.

Di samping itu, Artikel 10 turut menekankan mengenai "kedudukan istimewa" beberapa segmen masyarakat di sisi undang-undang, antaranya termasuklah kanak-kanak. Hal ini menjadikan kanakkanak memperoleh keistimewaan dan dijamin di sisi undang-undang, yang semestinya turut menjamin penambah baikan di dalam pendidikan mereka. Di Turki, pendidikan merupakan antara medan yang kerap mencetuskan perdebatan hangat antara kelompok Islam-konservatif dan kelompok sekular, hatta pada era mutakhir. Misalnya, perundangan Turki menetapkan bahawa pengajaran al-Qur'an untuk kanak-kanak di bawah umur 12 tahun adalah dilarang kerana dilihat bertentangan dengan aspirasi sekularisme yang termaktub di dalam perlembagaan. ${ }^{72}$ Pindaan terhadap Artikel 10 mempunyai potensi untuk meleraikan pertikaian yang melibatkan hal ehwal pendidikan kanak-kanak. Keistimewaan yang dijamin di bawah perlembagaan memberi peluang dan ruang yang lebih luas kepada kanak-kanak untuk akses kepada kelas pengajaran al-Qur'an dan kelas-kelas pengajaran agama yang lain.

Di samping pindaan pada Artikel 10, pindaan yang melibatkan penubuhan Ombudsman turut memberi kesan kepada perkembangan demokrasi di Turki. Penubuhan Ombudsman merupakan inisiatif yang diusahakan bagi menghubungkan secara langsung antara rakyat dan negara. ${ }^{73}$ Ombudsman adalah sebuah badan undang-undang yang bebas serta tidak memihak, bertujuan untuk melindungi rakyat daripada kepincangan dan salah laku pengurusan dengan bertindak berdasarkan aduan yang diterima. ${ }^{74}$ Ia bukan sahaja membolehkan rakyat Turki menyuarakan aduan mereka berhubung kerenah birokrasi serta permasalahan pengurusan baik di tempat kerja mahupun di peringkat institusi negara, malah turut memberi ruang penyaluran idea untuk pembangunan negara. Mekanisme pengauditan melalui Ombudsman menjuruskan Turki menjadi sebuah negara yang mengutamakan konsep ketelusan, memberi ruang kepada rakyat untuk terlibat dalam menyumbang kepada pembinaan negara serta meningkatkan imej Turki dari perspektif demokrasi dan hak asasi. ${ }^{75}$

Di samping Ombudsman, hak dan ruang awam rakyat Turki turut diperkasakan melalui kebenaran untuk membuat aduan secara terus kepada Mahkamah Perlembagaan. Sejak diperkenalkan menerusi Perlembagaan 1961, buat pertama kalinya permohonan secara individu di Mahkamah Perlembagaan

\footnotetext{
${ }^{69}$ Article 166 Constitution of Republic Turkey, h. 89.

${ }^{70}$ Bilal Sambur (2009), "The Great Transformation of Political Islam in Turkey: The Case of Justice and Development Party and Erdogan," European Journal of Economic and Political Studies, Jil. 2, Bil. 2, h. 122-126.

${ }_{71}$ Article 10 Constitution of Republic Turkey, h. 4.

${ }^{72}$ Rafiq ibn Jubair (2016), "7 Ways Turkey Has Become More Islamic Under the Leadership of President Erdoğan," ilmfeed, dicapai 31 Oktober 2017, http://ilmfeed.com/7-ways-turkey-has-become-more-islamic-under-the-leadership-of-president-erdogan/; Hakan Köni dan Meryem Açıköz (2013), "Politics of Religion in Turkey from National View to the Justice and Development Party," International Journal of Research in Social Sciences, Jil. 3, Bil.2, h. 54-55.

${ }^{73}$ Gönenç (2010), “2010 Proposed Constitutional Amendments,” h. 2.

${ }^{74}$ Karasoy (2015), "Ombudsman in Turkey," h. 47.

${ }^{75}$ Karasoy (2015), “Ombudsman in Turkey,” h. 53
} 
dibenarkan hasil daripada pindaan perlembagaan pada tahun 2010. Pindaan ini membolehkan sesiapa sahaja untuk terus merujuk kepada Mahkamah Perlembagaan jika terdapat hal-hal berbangkit yang melibatkan pelanggaran perlembagaan mahupun kes pencabulan hak asasi. Sepanjang sejarah Turki moden, kes pelanggaran kebebasan dan hak asasi kerap kali berlaku. Dalam kes pemakaian tudung misalnya, ia sering digambarkan oleh kelompok sekular sebagai simbol Islam dan mencabar prinsip sekularisme Atatürk. ${ }^{76} \mathrm{Hal}$ ini menyebabkan hak pemakaian tudung kerap kali dinafikan. Mereka yang pernah menjadi mangsa penafian hak untuk memakai tudung terdiri daripada pelajar di universiti, penjawat awam dan termasuk ahli parlimen. Melalui pindaan yang dibuat pada Artikel 148, perubahan terhadap fungsi Mahkamah Perlembagaan telah memperkukuhkan lagi ruang awam dan hak asasi rakyat Turki melalui jaminan di dalam perlembagaan.

\section{Kesan kepada Tentera}

Selain itu, pindaan perlembagaan tahun 2010 turut memberi kesan langsung terhadap institusi tentera. Sebelum pindaan perlembagaan dibuat, tentera yang didapati bersalah atau melanggar tatatertib akan diadili di mahkamah tentera, tidak di mahkamah awam. Mahkamah tentera berperanan untuk membicarakan kesalahan yang dilakukan oleh anggota tentera, kesalahan yang dilakukan oleh manamana individu tentera terhadap anggota tentera yang lain atau bagi sebarang kes yang berkaitan dengan hal ehwal perkhidmatan dan tugas tentera. ${ }^{77} \mathrm{Hal}$ ini menjadikan tentera sebagai sebuah institusi yang mempunyai kedudukan istimewa dan dari sudut yang lain pula memperlihatkan wujud unsur ketidak telusan dalam membicarakan individu tentera. Tambahan pula, mahkamah tentera turut berhak membicarakan individu bukan tentera bagi kesalahan-kesalahan tertentu yang tertakluk di bawah perbicaraan mahkamah tentera. ${ }^{78}$ Namun, pindaan Artikel 145 telah mengubah senario-senario di atas dengan menetapkan, seseorang pegawai tentera harus diadili di mahkamah awam bagi kes yang tidak melibatkan hal ehwal ketenteraan, setara dengan rakyat awam yang lain. Manakala individu selain tentera tidak boleh dibicarakan di bawah mahkamah tentera melainkan semasa darurat atau perang sahaja.

Selain itu, pindaan perlembagaan tahun 2010 turut membolehkan pegawai-pegawai atasan tentera untuk dibicarakan di Mahkamah Perlembagaan. Jika merujuk kepada peruntukan sebelumnya, Artikel 148 yang memerihalkan fungsi Mahkamah Perlembagaan tidak dinyatakan mengenai kuasanya bagi membicarakan pegawai atasan tentera. ${ }^{79}$ Selepas pindaan tahun 2010, artikel berkenaan telah ditambah dengan perenggan baharu yang membolehkan Mahkamah Perlembagaan selaku mahkamah agung untuk membicarakan Ketua Turus Angkatan Tentera, komander-komander angkatan tentera darat, laut dan udara serta Panglima Besar Gendarmerie terhadap salah laku tugas mereka. Secara tidak langsung, pindaan tersebut telah membuang imuniti atau kekebalan perundangan yang dikecapi oleh pegawai tertinggi institusi tentera sebelumnya. Dengan ini, tentera bukan sahaja diadili di mahkamah tentera di atas salah laku perkhidmatan, malah turut boleh diadili di Mahkamah Perlembagaan, khususnya bagi kes-kes yang melibatkan pelanggaran perlembagaan negara.

Tidak sekadar itu, pemansuhan Artikel Sementara 15 turut membuang kekebalan perundangan yang diberikan terhadap anggota tentera yang terlibat di dalam rampasan kuasa pada tahun 1980. Jika disoroti, rampasan kuasa pada tahun 1980 merupakan campur tangan tentera yang paling tragik jika dibandingkan dengan tiga siri rampasan kuasa yang lain iaitu pada tahun 1960, 1971 dan 1997. Ini kerana rampasan kuasa tersebut menyebabkan cengkaman tentera terhadap rakyat semakin kuat ${ }^{80} \mathrm{di}$ samping penutupan secara meluas parti-parti politik dan pertubuhan sosial. ${ }^{81}$ Malah, ia turut memberi kesan sehingga 30 tahun selepasnya yang dapat dilihat menerusi larangan pemakaian tudung di universiti ${ }^{82}$ serta penggubalan Perlembagaan Turki yang bersifat autoritarian dan masih lagi diguna pakai. Penulis berpandangan, pemansuhan imuniti dan tindakan undang-undang yang boleh dikenakan kepada penggerak rampasan kuasa tersebut, sekiranya disabit bersalah, adalah suatu yang signifikan memandangkan rampasan kuasa tahun 1980 telah menatijahkan kepada konflik dan ketegangan politik

\footnotetext{
${ }^{76}$ Dilek Cindoglu dan Gizem Zencirci (2008), “The Headscarf in Turkey in the Public and State Spheres,” Middle Eastern Studies, Jil. 44, Bil. 5, h. 792

77 Article 145 Constitution of Republic Turkey, h. 72.

78 "Article 145 Constitution of the Republic of Turkey."

79 "Article 148 Constitution of the Republic of Turkey."

${ }^{80}$ Begüm Burak (2011), "The Role of the Military in Turkish Politics: To Guard Whom and From What?" European Journal of Economic and Political Studies, Jil. 4, Bil. 1, h. 152.

${ }^{81}$ Özbudun (2012), "Turkey's Search for a New Constitution," h. 41.

${ }^{82}$ Fatma Nevra Seggie (2015), "Academic and Cultural Experiences of Covered Women in Turkish Higher Education," Comparative Education, Jil. 51, Bil. 4, h. 579.
} 
yang berpanjangan di Turki. Pada masa yang sama, pemansuhan Artikel Sementara 15 boleh bertindak sebagai amaran kepada pihak tentera supaya tidak lagi sewenang-wenangnya mencampuri urusan pentadbiran negara.

Perubahan terhadap struktur dan fungsi Mahkamah Perlembagaan turut memberi kesan kepada proses pengadilan tentera. Selama ini, institusi kehakiman kerap kali memihak kepada pendirian kelompok sekular dan tentera dalam mengadili sesuatu kes. Misalnya, campur tangan tentera pada tahun 1997, atau disebut juga sebagai "rampasan kuasa pascamoden" dilakukan berdasarkan dakwaan bahawa parti pro-Islam; Parti Kebajikan (Refah Partisi, RP) yang menjadi kerajaan ketika itu telah mencabar prinsip sekularisme. Seterusnya, ia disusuli dengan pembubaran RP oleh Mahkamah Perlembagaan. ${ }^{83}$ Manakala pada tahun 2007, tentera telah memuat naik e-memorandum di laman web rasmi mereka dan mengancam untuk melakukan campur tangan jika AKP meneruskan hasrat untuk menamakan calon Presiden. ${ }^{84}$ Walaupun tindakan provokatif tersebut berpotensi mencetuskan ketidak stabilan dalam kalangan masyarakat, tiada tindakan yang diambil terhadap segelintir tentera yang berkenaan hatta dari pihak Mahkamah Perlembagaan sendiri. Hal ini menggambarkan wujudnya keterikatan yang kuat antara institusi kehakiman, khususnya Mahkamah Perlembagaan, dan pihak tentera berdasarkan kepentingan-kepentingan yang tertentu.

Namun, pindaan perlembagaan tahun 2010 telah mengubah keadaan ini menerusi pemansuhan imuniti yang diperolehi tentera. Dalam konteks institusi tentera, pindaan perlembagaan yang membolehkan pegawai tertinggi tentera dibicarakan di mahkamah selain mahkamah tentera merupakan kejayaan AKP dalam memecahkan dominasi dan kedudukan istimewa yang dikecapi oleh tentera selama ini. Pemilihan anggota Mahkamah Perlembagaan yang lebih telus selepas pindaan perlembagaan tahun 2010 turut menjamin proses pengadilan tentera yang lebih profesional. Dengan ini, pihak tentera tidak boleh sewenang-wenangnya melakukan sebarang tindakan berdasarkan tafsiran dan perkiraan mereka sematamata, khususnya yang melibatkan tindakan-tindakan yang tidak demokratik. ${ }^{85}$ Perubahan-perubahan ini turut menjadikan institusi tentera tidak lagi kebal daripada disentuh oleh perundangan dan terlalu berkuasa terhadap pemerintah sivil yang dipilih rakyat. ${ }^{86}$

\section{Kesan kepada Badan Kehakiman}

Selain memberi kesan kepada pemerkasaan demokrasi dan tentera, pindaan perlembagaan tahun 2010 turut memberi kesan kepada badan kehakiman. Pindaan terhadap artikel-artikel yang melibatkan badan kehakiman adalah yang terbanyak berbanding artikel-artikel di bawah kategori yang lain. Secara keseluruhannya, pindaan di bawah kategori kehakiman melibatkan sembilan artikel iaitu Artikel 144, $145,146,147,148,149,156,157$ dan 159. Tumpuan yang diberikan terhadap badan kehakiman menerusi pakej pindaan perlembagaan tahun 2010 merupakan usaha AKP bagi menstrukturkan semula dan mengehadkan bidang kuasa badan kehakiman. Dalam hal ini, Mahkamah Perlembagaan selaku mahkamah tertinggi telah mengalami perubahan struktur serta fungsi yang jelas. Peruntukan baharu di dalam Artikel 146 memberi ruang kepada pertambahan ahli Mahkamah Perlembagaan daripada 11 orang kepada 17 orang. Pelantikan keanggotaan mahkamah tersebut dipilih oleh Presiden seramai 14 orang, manakala selebihnya dipilih melalui parlimen. Dari sudut komposisi ahli, Mahkamah Perlembagaan dianggotai seramai dua orang daripada Mahkamah Berbilang (Court of Accounts), seorang dipilih daripada Majlis Peguam, tiga orang daripada Mahkamah Tinggi Rayuan (Court of Cassation), dua orang daripada Dewan Negara, seorang masing-masing daripada Mahkamah Rayuan Tentera (Military Court of Cassation) dan Mahkamah Pentadbiran Tinggi Tentera (High Military Administrative Court), tiga orang dari kalangan ahli akademik serta empat orang lagi bekas peguam. ${ }^{87}$ Di samping komposisi ahli, pindaan pada Artikel 147 pula memperincikan mengenai status keanggotaan Mahkamah Perlembagaan. Dengan mengekalkan had umur keanggotaan kepada 65 tahun, pindaan tahun 2010 turut menambah mengenai tempoh keahlian mestilah dalam tempoh maksimum selama 12 tahun. Mereka yang dipilih untuk satu-satu sesi pula tidak boleh dipilih sekali lagi di masa akan datang. ${ }^{88}$

\footnotetext{
${ }^{83}$ Burak (2011), "The Role of the Military in Turkish Politics,” h. 153

${ }^{84}$ Redzuan dan Mashitah (2015), Sekularisme dan Proses Demokrasi di Turki, h. 179-180.

${ }^{85}$ Ahmad Dzakirin (2012), Kebangkitan Gerakan Islam: Analisis Strategi dan Polisi AKP Turki Memenangi Pilihanraya Umum, Kuala Lumpur: Alam Raya Enterprise, h. 107.

${ }^{86}$ Berk Esen dan Sebnem Gumuscu (2016), "Rising Competitive Authoritarianism in Turkey,” Third World Quarterly, Jil. 37, Bil. 9, h. 15841585 .

${ }^{87}$ Article 146 Constitution of Republic Turkey, h. 73-74.

${ }^{88}$ Article 147 Constitution of Republic Turkey, h. 75.
} 
Turut menerima kesan ketara daripada pindaan perlembagaan tahun 2010 ialah struktur HSYK. Di bawah peruntukan baharu, berlaku penambahan ahli HSYK daripada tujuh orang kepada 22 orang ahli tetap beserta 12 orang ahli simpanan. Dari sudut komposisi ahli, organisasi HSYK terdiri daripada Menteri Keadilan selaku pengerusi HSYK, Setiausaha Tetap sebagai ahli ex-officio dan diikuti tujuh daripadanya dipilih dalam kalangan hakim dan pendakwa raya daripada mahkamah awam, tiga daripada hakim dan pendakwa raya mahkamah pentadbiran, tiga daripada Mahkamah Tinggi Rayuan, dua daripada Dewan Negara, seorang daripada Akademi Keadilan Tentera dan empat orang lagi dipilih oleh Presiden dalam kalangan ahli akademik, pengamal undang-undang dan peguam. ${ }^{89}$ Di samping itu, pindaan perlembagaan tahun 2010 turut menjadikan HSYK sebagai sebuah entiti yang bebas dari sudut pentadbiran dan kewangannya, di mana ia perlu mempunyai bajet, bangunan dan sekretariatnya yang tersendiri. ${ }^{90}$

Jika diteliti, usaha kerajaan AKP meminda peruntukan-peruntukan yang melibatkan struktur Mahkamah Perlembagaan dan HSYK boleh dianalisis sebagai strategi bagi memastikan posisi-posisi di dalam institusi kehakiman tidak lagi dimonopoli oleh pihak-pihak tertentu. Misalnya, pelantikan ahli Mahkamah Perlembagaan terdahulu dibuat hanya melibatkan sekumpulan kecil elit tentera. ${ }^{91}$ Pindaan terhadap Artikel 146 dan 147 boleh dinilai sebagai inisiatif AKP bagi memecahkan dominasi elit tentera yang berselindung di sebalik institusi kehakiman negara. Malah, pemilihan ahli bagi kedua-dua institusi berkenaan dibuat berdasarkan kepada kepakaran dan kelayakan yang diiktiraf, sekaligus memperlihatkan ketelusan dalam pembentukan organisasi Mahkamah Perlembagaan dan HSYK. Perubahan yang dilakukan juga merupakan sebahagian daripada usaha bagi membebaskan institusi kehakiman daripada didominasi oleh pihak-pihak tertentu, di samping menjadikan ia lebih menyeluruh dari sudut cakupan keanggotaannya.

Pertambahan bilangan anggota Mahkamah Perlembagaan seperti yang diperuntukkan di dalam Artikel 146 merupakan satu perkembangan penting dalam konteks perubahan corak kuasa mahkamah tersebut. Selain merupakan usaha bagi menempatkan mereka yang selayaknya bagi menganggotai Mahkamah Perlembagaan, pertambahan bilangan anggota daripada 11 orang kepada 17 orang juga memberi kesan kepada kuasa mahkamah tersebut dalam membuat sesuatu keputusan besar. Sebelumnya, sesuatu keputusan akan dicapai sekiranya bilangan panel hakim yang menyokong atau menolak mencapai tujuh daripada 11 orang panel hakim. Hal inilah yang berlaku semasa cadangan bagi meminda Artikel 10 dan Artikel 42 ditolak oleh Mahkamah Perlembagaan pada tahun 2008. Dengan berlakunya penambahan bilangan panel hakim lebih-lebih lagi menerusi mekanisme pemilihan yang lebih telus, Mahkamah Perlembagaan akan menjadi sebuah institusi kehakiman yang lebih rencam, demokratik serta tidak lagi secara mudah memutuskan sesuatu keputusan seperti sebelumnya.

Selain itu, pindaan terhadap Artikel 149 juga adalah penting untuk dibincangkan. Artikel tersebut memperuntukkan kuasa kepada Mahkamah Perlembagaan untuk membatalkan sesuatu pindaan perlembagaan serta mengambil tindakan terhadap parti-parti politik sama ada dengan membubarkan parti tersebut atau memotong perbelanjaan yang diperuntukkan oleh negara kepada parti-parti politik. Pindaan terhadap Artikel 149 telah menetapkan bahawa korum anggota Mahkamah Perlembagaan perlulah mencapai dua pertiga kehadiran bagi memulakan sesuatu perbicaraan. ${ }^{92}$ Penetapan ini menjadikan tindakan terhadap parti-parti politik serta pembatalan sesuatu pindaan perlembagaan yang diusulkan tidak semudah sepertimana sebelumnya, lebih-lebih lagi dengan pertambahan anggota Mahkamah Perlembagaan. Adalah tidak dinafikan bahawa kuasa untuk membubarkan parti politik sememangnya merupakan keperluan buat Mahkamah Perlembagaan sebagai mekanisme pencegahan terhadap sebarang unsur yang berpotensi menyanggahi perlembagaan negara oleh mana-mana parti politik. Namun, kuasa yang kurang dibataskan boleh menjerumuskan mahkamah tersebut menjadi sebuah institusi yang berkuasa untuk mengharamkan mana-mana parti politik di atas kepentingan tertentu tanpa sebab yang sewajarnya.

Jika disoroti, banyak parti politik yang tidak sehaluan dengan aspirasi elit sekular yang telah diharamkan oleh Mahkamah Perlembagaan. AKP turut tidak terkecuali daripada hampir diharamkan di atas dakwaan "menjadi pusat kepada kegiatan anti-sekular" hanya kerana memperjuangkan hak pelajar

\footnotetext{
${ }^{89}$ Ergun Özbudun (2011), “Turkey's Constitutional Reform and the 2010 Constitutional Reform,” Mediterranean Politics, h. 194

90 Özbudun (2012), "Turkey's Search for a New Constitution," h. 48.

${ }^{91}$ Redzuan dan Mashitah (2015), Sekularisme dan Proses Demokrasi di Turki, h. 114.

${ }^{92}$ Article 149 Constitution of Republic Turkey, h. 77.
} 
universiti untuk memakai tudung. ${ }^{93}$ Meskipun pindaan terhadap Artikel 69 yang mengehadkan kuasa mahkamah untuk membubarkan parti politik tidak dapat dilaksanakan kerana tidak mendapat undian yang mencukupi, pindaan terhadap Artikel 149 ini sedikit sebanyak boleh menyumbang kepada kesinambungan parti-parti politik di Turki, khususnya yang beraspirasikan Islam. Tambahan pula, pindaan terhadap Artikel 84 memberikan jaminan kepada ahli parlimen sekiranya parti yang diwakilinya diharamkan oleh Mahkamah Perlembagaan sekalipun, kedudukannya sebagai ahli parlimen tetap diteruskan.

\section{Kesimpulan}

Jika disoroti, Perlembagaan Turki menjadi antara subjek yang banyak mencorak perkembangan politik di Turki sama ada mengenai jatuh bangun sesebuah kerajaan yang dipilih secara sah oleh rakyat, pengharaman sesebuah parti politik, mahupun campur tangan politik yang dilakukan oleh pihak tentera. Kesemua peristiwa yang berlaku ini sering dijustifikasikan berdasarkan hujah keperlembagaan. Justeru, adalah dapat difahami mengapa AKP memberi tumpuan secara khusus kepada perlembagaan negara sebagai salah satu sasarannya dalam melakukan proses pendemokrasian; iaitu bagi mereformasikan Perlembagaan Turki supaya lebih menepati kehendak demokrasi, di samping mengurangkan keluasan pengaruh tentera dan badan kehakiman.

Penulis melihat- kejayaan bagi meminda perlembagaan pada tahun 2010 memberi isyarat yang jelas berdasarkan beberapa aspek iaitu: i) kejayaan AKP bagi menundukkan institusi tentera; ii) kejayaan merombak badan kehakiman tertinggi supaya berfungsi secara lebih neutral dan profesional; iii) wujudnya kehendak rakyat untuk memastikan kelangsungan demokrasi di Turki; iv) kemenangan moral buat AKP yang dilihat sebagai pejuang demokrasi tulen; dan v) mengisyaratkan berakhirnya era pendominasian elit sekular dalam spektrum pentadbiran Turki. Namun, antara kesemua aspek ini, kejayaan untuk melaksanakan proses pendemokrasian di Turki merupakan kejayaan yang paling utama daripada pindaan perlembagaan yang dilakukan.

Di Turki, proses pendemokrasian merupakan elemen yang penting dalam konteks pengamalan Islam berdasarkan dua sudut. Pertama, suasana demokrasi menjamin ruang dan hak asasi rakyat untuk mengamalkan tuntutan agama tanpa diskriminasi. Sepertimana yang telah dibincangkan di atas, beberapa pindaan yang dilakukan telah membuka ruang kebebasan untuk pengamalan Islam yang sering didiskriminasi seperti memakai tudung serta mendapat pendidikan agama secara bebas. Kedua, proses pendemokrasian berupaya mengekang elit sekular yang sentiasa menyekat pengamalan Islam secara bebas. Misalnya, pindaan perlembagaan tahun 2010 menyebabkan Mahkamah Perlembagaan perlu bertindak secara lebih telus serta perlu mengimbangi antara keperluan memelihara prinsip sekularisme di satu sudut, dan keperluan untuk menjunjung semangat demokrasi di sudut yang lain. Meskipun pindaan perlembagaan tahun 2010 bukanlah inisiatif pendemokrasian yang sempurna, namun ia memadai untuk membuka ruang baharu kepada negara Turki yang lebih bebas dan demokratik. Sebagai sebuah negara sekular, proses pendemokrasian merupakan langkah yang berkesan di Turki untuk membuka ruang kepada kebebasan pengamalan agama masyarakat.

\section{Rujukan}

Ahmad Dzakirin (2012), Kebangkitan Gerakan Islam: Analisis Strategi dan Polisi AKP Turki Memenangi Pilihanraya Umum, Kuala Lumpur: Alam Raya Enterprise.

Al Jazeera Centre for Studies (2010), Implications of the Turkish Referendum on Constitutional Amendments, Doha: Al Jazeera Network.

Balkan, Sadık, Uysal, Ahmet E. dan Karpat, Kemal H. (1961), Constitution of the Turkish Republic, Ankara.

Burak, Begüm (2011), "The Role of the Military in Turkish Politics: To Guard Whom and From What?" European Journal of Economic and Political Studies, Jil. 4, Bil. 1, 143-169.

\footnotetext{
${ }^{93}$ Untuk mengetahui dengan lebih lanjut mengenai usaha pengharaman AKP, lihat Metin Toprak dan Nasuh Uslu (2009), "The Headscarf Controversy in Turkey," Journal of Economic and Social Research, Jil. 11, Bil. 1, h. 48; Özbudun (2012), "Turkey's Search for a New Constitution," h. 46.
} 
Ciddi, Sinan (2011), “Turkey's September 12, 2010, Referendum," Rubin Center, dicapai 14 Oktober 2017, http://www.rubincenter.org/2011/12/turkey\%E2\%80\%99s-september-12-2010-referendum/.

Cindoglu, Dilek dan Zencirci, Gizem (2008), "The Headscarf in Turkey in the Public and State Spheres," Middle Eastern Studies, Jil. 44, Bil. 5, 791-806.

Constitution of the Republic Turkey (1982), Egemenlik Kayitsiz Şatsiz Milletindir.

Constitution of the Republic Turkey (sebelum pindaan) (1982), Refworld, diakses dari http://www.unhcr.org/refworld/docid/3ae6b5be0.html.

Earle, Edward Mead (1925), “The New Constitution of Turkey," Political Science Quarterly, Jil. 40, Bil. 1, 89-100.

Esen, Berk dan Gumuscu, Sebnem (2016), "Rising Competitive Authoritarianism in Turkey," Third World Quarterly, Jil. 39, Bil. 9, 1581-1606.

Ete, Hatem, Y1lmaz, Nuh dan Üstün, Kadir (2011), "Turkey’s Constitutional Referendum of 2010 and Insights for The General Elections of 2011," Seta Policy Report.

Friedrich Ebert Stiftung (2011), "On the Way to a New Constitution in Turkey: Consitutional History, Political Parties and Civil Platform," dicapai 3 November 2017, http://library.fes.de/pdffiles/bueros/tuerkei/12220.pdf.

Gençkaya, Ö. F. (t.t.), “The 1921 Constitution (Selections)," Anayasa, dicapai 17 September 2017, http://genckaya.bilkent.edu.tr/1921C.html.

Giritli, Ismet (1962), "Some aspects of the new Turkish Constitution," The Middle East Journal, Jil. 16, Bil. 1, 1-17.

Gönenç, Levent (2004), "The 2001 Amendments to the 1982 Constitution of Turkey," Ankara Law Review, Jil. 1, Bil. 1, 89-109.

Gönenç, Levent (2010), "2010 Proposed Constitutional Amendments to the 1982 Constitution of Turkey," TEPAV Evaluation Note.

Head, Jonathan (2010), "Referendum result fails to mask Turkey's divisions," BBC News, dicapai 4 Januari 2018, http://www.bbc.com/news/world-europe-11288360.

Herzog, Marc (2010), FPC Briefing: Analysing Turkey's 2010 Constitutional Referendum, London: The Foreign Policy Centre.

ibn Jubair, Rafiq (2016), "7 Ways Turkey Has Become More Islamic Under the Leadership of President Erdoğan," ilmfeed, dicapai 31 Oktober 2017, http://ilmfeed.com/7-ways-turkey-has-become-moreislamic-under-the-leadership-of-president-erdogan/.

Jung, Dietrich (2010), The Constitutional Referendum in Turkey: A Step Toward Democracy?, Odense: Center for Mellemøststudier, Syddansk Universitet.

Karasoy, H. Alpay (2015), "Ombudsman in Turkey: Its Contributions and Criticism," European Scientific Journal, Jil. 11, Bil. 22, 46-59.

Köni, Hakan dan Açıkgöz, Meryem (2013), "Politics of Religion in Turkey from National View to the Justice and Development Party," International Journal of Research in Social Sciences, Jil. 3, Bil.2, 4856.

Kubicek, Paul (2005), "The European Union and Grassroots Democratization in Turkey," Turkish Studies, Jil. 6, Bil. 3, 361-377. 
Maksudoğlu, Mehmet (1999), Osmanlı History 1289-1922: Based on Osmanl Sources, Gombak: Research Centre, International Islamic University Malaysia.

Mohamad Shaukhi Mohd Radzi (2016), Proses Pembaratan dalam Daulah Uthmaniyyah 1789-1876, Sabah: Penerbit Universiti Malaysia Sabah.

Mohammad Redzuan Othman dan Mashitah Sulaiman (2015), Sekularisme dan Proses Demokrasi di Turki: Pemerkasaan Islam dan Kepimpinan Erdogan, Kuala Lumpur: Penerbit Universiti Malaya.

Özbudun, Ergun (2007), “Democratization Reforms in Turkey, 1993-2004,” Turkish Studies, Jil. 8, Bil. 2, 179-196.

Özbudun, Ergun (2011), "Turkey's Constitutional Reform and the 2010 Constitutional Reform," Mediterranean Politics, 191-194.

Özbudun, Ergun (2012), “Turkey's Search for a New Constitution,” Insight Turkey, Jil. 14, Bil. 1, 3950.

Sakallioğlu, Ümit Cizre (1997), "The Anatomy of the Turkish Military's Political Autonomy," Comparative Politics, Jil. 29, Bil.2,

Saktanber, Ayse dan Çorbacioğlu, Gül (2008), "Veiling and Headscarf-Skepticism in Turkey," Social Politics, Jil. 15, Bil. 4, 151-166.

Sambur, Bilal (2009), "The Great Transformation of Political Islam in Turkey: The Case of Justice and Development Party and Erdogan," European Journal of Economic and Political Studies, Jil. 2, Bil. 2, 117-127.

Seggie, Fatma Nevra (2015), "Academic and Cultural Experiences of Covered Women in Turkish Higher Education," Comparative Education, Jil. 51, Bil. 4, 575-591.

Sencer, Muzaffer (t.t.), "From the Constitution 1961 to the Constitution 1982," Turkish Yearbook of Human Rights.

Toprak, Metin dan Uslu, Nasuh (2009), “The Headscarf Controversy in Turkey," Journal of Economic and Social Research, Jil. 11, Bil. 1, 43-67.

Topukcu, Asl1 (2014), "The Processes and the Principles of Constitutional Design in Turkey: Historical and Legal Perspective," Makalah, World Congress of Constitutional Law 2014, Oslo, Norway, 16-20 Jun.

Varol, Ozan O. (2013), "The Turkish "Model” of Civil-Military Relations," International Journal of Constitutional Law, Jil. 11, Bil. 3, 727-750. 
Journal of Al-Tamaddun, Vol. 15 (2), 2020, 177-195 